\title{
Modelling spontaneous combustion liability of carbonaceous materials
}

\author{
M. Onifade ${ }^{1} \cdot$ B. Genc ${ }^{1}$ (I)
}

Received: 27 March 2018/Revised: 22 May 2018/Accepted: 5 June 2018/Published online: 15 June 2018

(C) The Author(s) 2018

\begin{abstract}
This paper presents predictive models to determine spontaneous combustion liability of carbonaceous materials (coals and coal-shales) using statistical analysis. The intrinsic properties and spontaneous combustion liability index were determined by testing 14 coals and 14 coal-shales from Witbank coalfields, South Africa. The relationship between these intrinsic properties (obtained from proximate, ultimate and petrographic analysis) and spontaneous combustion liability indices (the Wits-Ehac Index and Wits-CT Index) were established. The influence of the intrinsic properties of coal-shales in relation to coal properties affecting spontaneous combustion has been established using a statistical method. The linear regression analysis indicates better linear relationships between some of the selected intrinsic properties and spontaneous combustion liability index and thus, identifies the major intrinsic factors affecting their liability toward spontaneous combustion. It was found that a definite positive or negative correlation coefficient exists between the intrinsic factors and spontaneous combustion liability. A set of models to predict the spontaneous combustion liability was derived. The best significant correlation along with the most appropriate model as indicated by R-squared values, the coefficient of correlations and standard error was used to predict the incident of spontaneous combustion.
\end{abstract}

Keywords Coals $\cdot$ Coal-shales $\cdot$ Statistical analysis $\cdot$ Wits-Ehac Index $\cdot$ Wits-CT Index $\cdot$ Spontaneous combustion

\section{Introduction}

The event of spontaneous combustion is the reason for several cases of fires in the coal mining industry. It is wellknown that carbonaceous materials such as coal and coalshales undergo self-heating when exposed to atmospheric conditions. Self-heating occurs naturally due to the chemical reactions between oxygen and coal and other carbonaceous materials. The spontaneous combustion characteristics of coal may be influenced by the natural

B. Genc

Bekir.Genc@wits.ac.za

M. Onifade

1519496@students.wits.ac.za

1 The School of Mining Engineering, University of the Witwatersrand, Johannesburg 2050, South Africa convection within a coal seam, waste dumps and other mining piles (Moghtaderi et al. 2000).

Self-heating of coal-shales has been reported in the South African coal mines to be capable of starting spontaneous combustion but not the coals alone (Onifade and Genc 2018b, c, d). This incident has been observed in areas such as overburden shales, selected bands of a coal seam, spoil heaps and highwall (Figs. 1,2). It is known that coal, roof shales and spoil heaps may become self-heated and liberate heat naturally under favourable weather conditions. Sedimentary rocks such as coal and coal-shale, consist of certain amounts of organic matter (macerals) and inorganic materials (mainly crystalline) causing them to likely undergo self-heating leading to spontaneous combustion (Onifade and Genc 2018d). Reactive sedimentary materials have pore spaces embedded in the solid together with the occurrence of a carbon-rich element (Dullien 1979). This renders the rock porous to different fluids like water and 

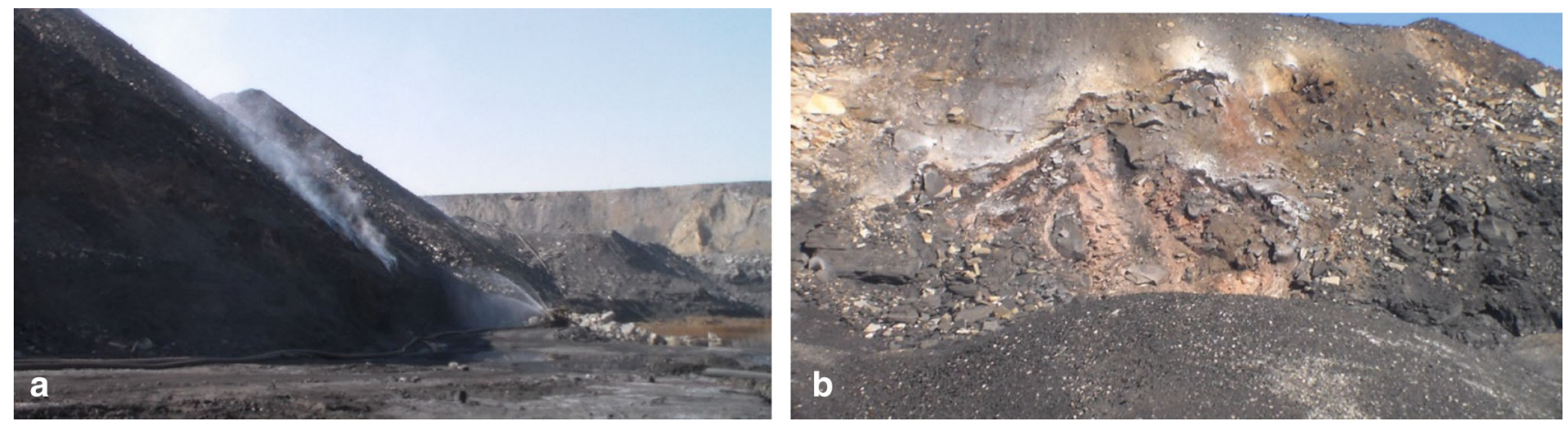

Fig. 1 a Self-heating of run-of-mine and b spoil heaps at Tweefontein Mine, Witbank, South Africa
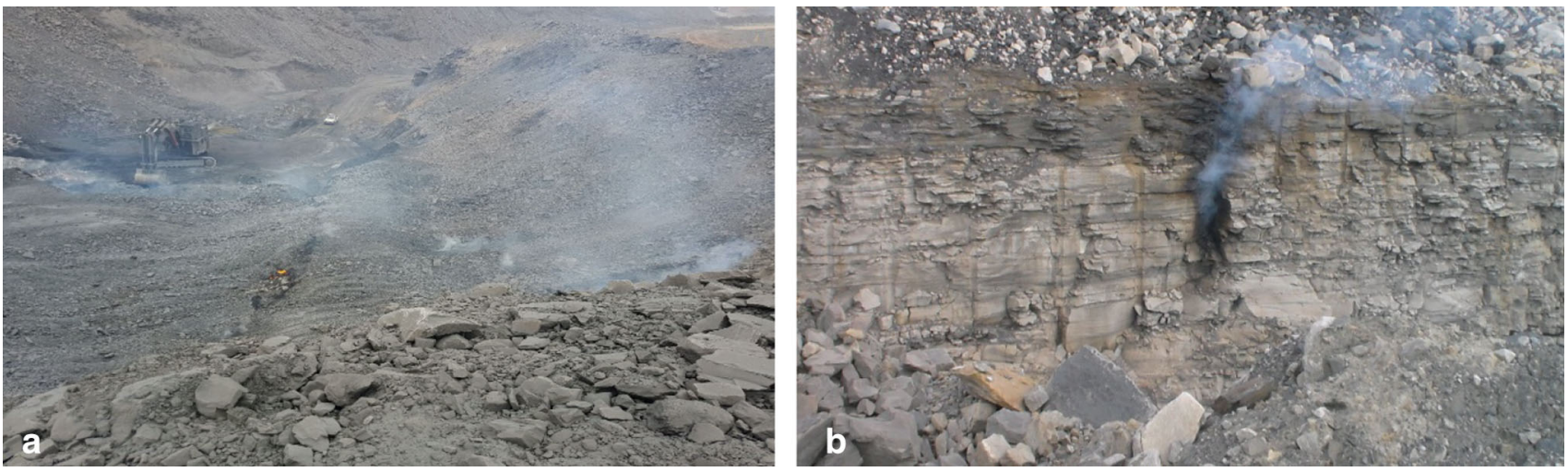

Fig. 2 a Signs of self-heating in coal seam at Khwezela Mine (Bokgoni Pit) and b self-heating of in-seam shale at Goedgevonden Colliery, Witbank, South Africa

air, increases its surface area, thus making the organic particles reactive as it permits oxidation to occur (Dullien 1979). Such reactive materials might experience spontaneous combustion. Spontaneous combustion of coals and coal-shales is an important phenomenon that requires indepth investigation. Studies of self-heating of coal-shales in selected bands of coal seams and highwalls are limited (Onifade et al. 2018; Onifade and Genc 2018d). Limited information is available to investigate and predict the spontaneous combustion liability of coal-shales in relation to coals. However, these are materials that comprise a number of varying microscopic and inorganic constituents for spontaneous combustion in old workings, spoil heaps and abandoned mines.

Many investigations have been carried out on the selfheating characteristics of coal, both experimentally and computationally (Gouws and Wade 1989a, b; Genc and Cook 2015; Stracher and Taylor 2004; Kucuk et al. 2003; Carras and Young 1994; Onifade et al. 2018; Onifade and Genc 2018b, c,d), but only limited studies exist on other reactive materials. The occurrence of various intrinsic and extrinsic parameters influencing the start and development of spontaneous combustion is the reason for the difficulties in understanding the mechanism of spontaneous combustion. Most of these parameters have been reported by many researchers (Kaymakci and Didari 2002; Banerjee 1985; Kim 1977; Beamish and Blazak 2005; Falcon 2004; Panigrahi and Sahu 2004; Panigrahi and Saxena 2001; Ren et al. 1999) to predict the self-heating characteristics of coal.

This study evaluated the intrinsic properties of some South African bituminous coals and coal-shales using characterisation tests (proximate, ultimate and petrographic analyses), following standard experimental procedures. Furthermore, a statistical interpretation of coals and coalshales analysis data and the combined effects of the major intrinsic factors affecting their liability towards spontaneous combustion for predictive purposes were examined. An understanding of these factors may be important in understanding the spontaneous combustion liability of coals and coal-shales in coal mines. 


\section{Materials and methods}

\subsection{Sample collection and preparation}

Fourteen coals and fourteen coal-shales used for this study were collected (using the ply sampling technique) from four coal mines (iMpunzi Mine, Goedgevonden Colliery, Khwezela Mine, and Tweefontenin Mine) in Witbank, South Africa. The samples were sealed in airtight bags (plastic), immediately after collection to avoid moisture loss and oxidation. The airtight bag is produced using aluminium-coated polyester which allows maximum reduction of vapour and oxygen permeability. Each ply sample bag was clearly labelled with a chosen number. Samples of bituminous coal and coal-shales were collected from a selected band of the coal seams (Witbank coalfields) and highwalls as shown in Figs. 1 and 2. The samples were selected in respect of their high propensity to oxidation from the areas known to be prone to spontaneous combustion. The samples were stored and prepared under laboratory conditions (room temperature). The sample lumps were reduced using a crusher (Rocklabs MK III) to suitable sizes $(>10 \mathrm{~mm}$ ). The samples were milled to $250 \mu \mathrm{m}$ size fraction for proximate, ultimate, total sulphur and forms of sulphur, $212 \mu \mathrm{m}$ for spontaneous combustion tests, while for petrographic analysis the samples were milled to $\leq 1000 \mu \mathrm{m}$ according to the South African National Standard (SANS, 7404 Parts 1-5), blended and divided using a centrifugal mill (Retsch ZM 200) to generate different sub-samples. Proximate, elemental and petrographic analysis, and spontaneous combustion tests (Wits-Ehac Index and Wits-CT Index) were carried out.

\subsection{Characterisation tests}

The experimental tests involving the determination of the moisture, ash, volatile matter and fixed carbon contents were carried out according to the American Society for Testing and Material (ASTM) standards (ASTM, D-317317a, ASTM, D-3174-11, ASTM, D-3175-17). Fixed carbon was obtained by subtracting the sum of the percentage of ash, moisture and volatile matter from 100 (ASTM, D317615). The carbon, hydrogen, nitrogen and total sulphur content were determined using a LECO TruSpec CHN and $\mathrm{C}$ and $\mathrm{S}$ analyzer according to the International Standard Organisation Standards (ISO 12902: 2001). Oxygen content was calculated by subtracting the sum of the percentage of moisture, ash, carbon, hydrogen, nitrogen and sulphur from 100. The results are reported in weight percent of air-dried (wt \%, ad). Pyritic sulphur was detected in selective digestion with hydrogen nitrate $\left(\mathrm{HNO}_{3}\right)$ and analysed by inductively coupled plasma optical emission
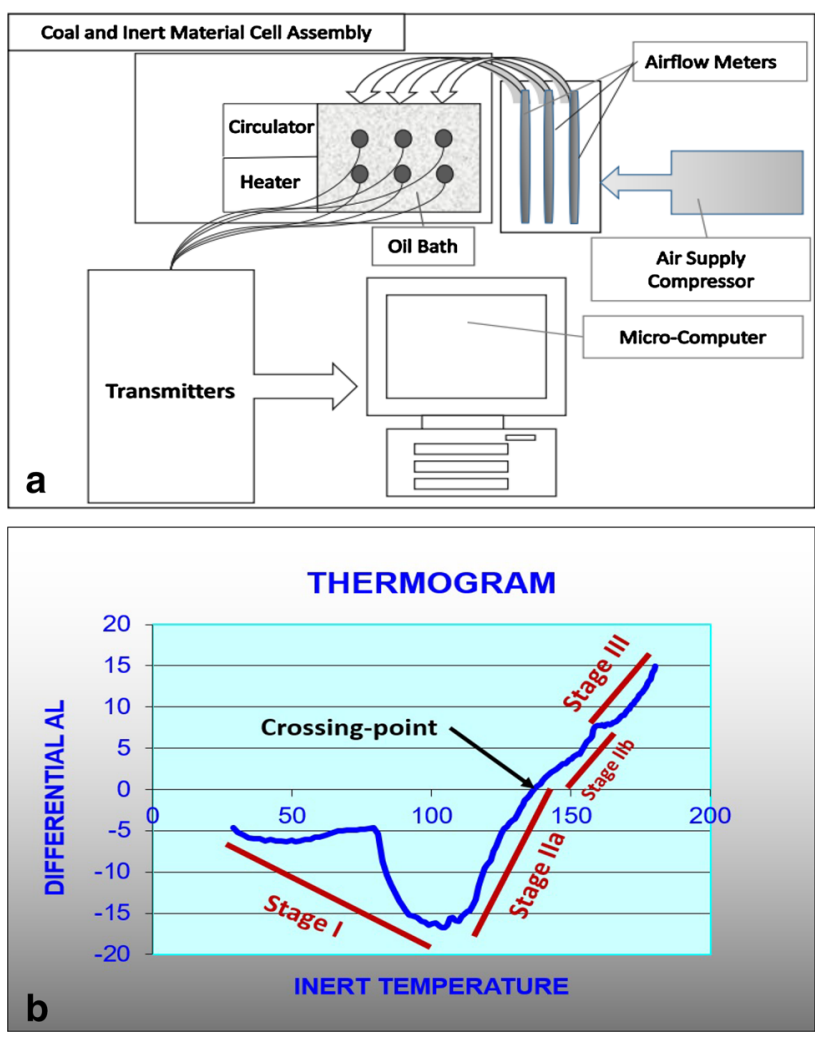

Fig. 3 a Wits-Ehac test apparatus set-up (Wade et al. 1987); b A typical differential analysis thermogram

(ICP-OES), while sulphate sulphur was detected in selective digestion with hydrogen chloride $(\mathrm{HCl})$ and analysed by photometric method as barium sulphate (BaSO4). Organic sulphur is taken as the difference between the total sulphur and the sum of the sulphate and pyritic sulphur. Maceral analysis including mineral matter was conducted to evaluate the organic and inorganic content of the samples. A Zeiss Axio Imager M2 M reflected light petrographic microscope fitted with oil immersion lens at a total magnification of $500 \times$ was used. The petrographic pellets and/or blocks used for the petrographic analyses were produced by mixing $2-3 \mathrm{~g}$ of the grain size specified $(\leq 1000 \mu \mathrm{m})$ according to the South African National Standard (SANS, 7404 Parts 1-5) with epoxy resin in a $3.2 \mathrm{~cm}$ diameter phenolic ring form moulds. The moulds were allowed to cure, and ground with the use of 320, 400 and 1000 grit papers. Once ground, they were polished using 1.0 and $0.3 \mu \mathrm{m}$ alumina slurries on various cloth. Final polishes were achieved with the use of colloidal silica, which provides relief free and scratch-free surfaces for analysis by reflectance microscopy. The macerals results including petrographically observable mineral matter are reported as volume percent ( $\mathrm{vol} \%$ ), inclusive of mineral matter or mineral matter free basis (vol\%, $\mathrm{mmf})$. 
Table 1 Criterion set for factors affecting spontaneous combustion liability of coals and coal-shales

\begin{tabular}{lll}
\hline Category & Criterion & Remarks \\
\hline 1 & $\begin{array}{c}\text { Correlation coefficient } \\
\text { between } 0.95 \text { and } 1 \text { or } \\
-0.95 \text { and }-1\end{array}$ & $\begin{array}{c}\text { Variable indicate a perfect } \\
\text { positive or negative } \\
\text { linear relationship }\end{array}$ \\
2 & $\begin{array}{c}\text { Correlation coefficient } \\
\text { between } 0.51 \text { and } 0.94 \text { or } \\
\end{array}$ & $\begin{array}{c}\text { Variable indicate a strong } \\
\text { positive or negative }\end{array}$ \\
& -0.51 and -0.94 & linear relationship \\
3 & Correlation coefficient & Variable indicate a \\
& between 0.25 and 0.50 or & moderate positive or \\
& -0.25 and -0.50 & negative linear \\
& & relationship \\
4 & Correlation coefficient & Variable indicate a weak \\
& between 0.1 and 0.24 or & positive or negative \\
& -0.1 and -2.24 & linear relationship \\
5 & Correlation coefficient $>$ & Variable indicate a very \\
& 0.1 but not zero & weak positive or negative \\
& & linear relationship \\
6 & Correlation coefficient of & Variable indicate no linear \\
& zero & relationship at all \\
\hline
\end{tabular}

\subsection{Wits-Ehac tests}

The Wits-Ehac Index was developed in South Africa in the late 1980s to test the spontaneous combustion liability of coal (Eroglu 1992; Genc et al. 2018; Genc and Cook 2015; Gouws and Wade 1989a, b; Onifade et al. 2018; Onifade and Genc 2018a, b, d; Wade 1989). The testing apparatus consists of an oil bath, six coal and inert material cell assemblies, an oil circular, a heater, a flowmeter, an air supply compressor and a computer (Wade et al. 1987) as shown in Fig. 3a. Freshly pulverized $(<212 \mu \mathrm{m})$ dried coal samples (under room temperature) of 20-25 g in weight is used. The test apparatus is used to test coals under predefined conditions and a spontaneous combustion liability index is obtained. The testing apparatus incorporates the determined crossing point temperatures (XPT) and differential thermal analysis (DTA) from selected coal samples with periodic measurement of temperatures to obtain a consistent self-heating liability index termed the Wits-Ehac Index. The coal temperatures are recorded every $30 \mathrm{~s}$ by the computer over an average of $4 \mathrm{~h}$ for the oil in the bath to be heated to $200{ }^{\circ} \mathrm{C}$. When the temperature difference between the inert material (calcined aluminium) and the coal sample is plotted against the inert temperature, the part of the graph where the coal is heating faster than the inert sample (where an exothermic reaction occurs) is termed Stage II. The index makes use of the fact that coal highly prone to self-heat have a steeper stage II slope and lower XPT than coal not highly prone to self-heat. When using DTA, the difference in temperatures between the coal sample and an inert material sample is measured via a data logger, stored in a computer and plotted against the temperature of the inert material sample. It is important to understand that during DTA, three stages are obtainable. At first, the temperature of an inert material sample is higher than the temperature of the coal sample (Stage 1), which is dependent on the cooling effect of the evaporation of the coal sample moisture content. Secondly, evaporation of the moisture content; the coal sample begins to heat up at a higher rate than the heating rate of the inert material (Stage II) and this is based on the liability of coal to self-heating and attempting to reach the temperature of the surrounding temperature (oil bath temperature). Lastly, the high exothermicity is reached at a point where the line crosses the zero base line and is referred to as the XPT. Uludag et al. (2001) indicated the three stages in a study and described that stage I starts with minimal differential and progressively increases towards the XPT where the differential is zero. Stage II continues from the XPT to the point referred to as kick-point. In addition, Stage II is one of the best indicators of spontaneous combustion. Stage III is when the coal starts to burn beyond the kick-point. According to Wade et al. (1987), coals with a spontaneous combustion liability index below 3 are considered to be low risk, 3-5 medium risk, and coals with values $>5$ are considered to be highly liable to spontaneous combustion. The index is calculated from the formula in Eq. 1. Using this formula, MS Excel calculates the stages and generates the thermogram (Fig. 3b).

Wits-Ehac Index $=($ Stage II slope $/$ XPT $) \times 500$

\subsection{Wits-CT tests}

The Wits-Ehac Index was developed in South Africa to test the spontaneous combustion liability of coal. However, in some cases, the Wits-Ehac Index fails to produce tangible results when testing coal-shales. To overcome this problem, a new apparatus has been developed to test coals and coal-shales under chemical reactions with oxygen and an index has been obtained (Onifade et al. 2018). A device for predicting the spontaneous combustion liability of coal, coal-shale and other carbonaceous materials under the influence of oxygen without any heating system was recently developed in the School of Mining Engineering, University of the Witwatersrand, and is referred to as the Wits-CT test. The liability of various samples to spontaneous combustion were evaluated for $24 \mathrm{~h}$ under the influence of oxygen. This experiment was designed to evaluate the temperature differences within the shortest period of time in a coal mass under the influence of oxygen.

The equipment has a capacity to accept a $15 \mathrm{~kg}$ sample, depending on the packing density. In order to determine 


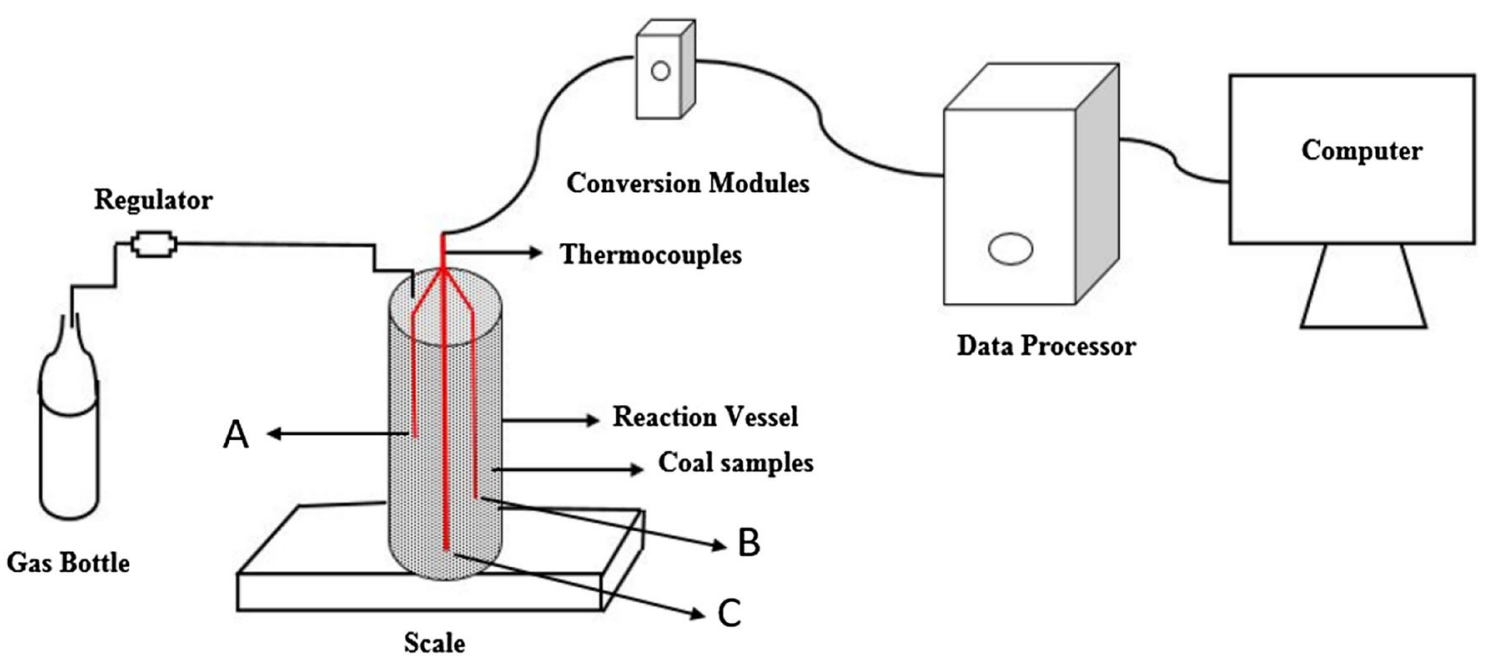

Fig. 4 Wits-CT apparatus (Onifade et al. 2018)

spontaneous combustion liability via self-heating, a representative sample of particle size $(<6.39 \mathrm{~mm})$ is weighed and loaded into an autoclave. The process is repeated until the autoclave is filled to the marked point and the lid is fixed and fastened as soon as the autoclave is full. This technique of preparation gives a closely sized sample that is preferable to measure the rate of oxidation. Three thermocouples each with two temperature probes are inserted into the column as the correct sample level is reached. Three uniformly separated temperature sensors placed along the length of the autoclave are used to check and record the temperature measurements. The sensor arrangement is typically located at different points within the autoclave (locations $\mathrm{A}, \mathrm{B}$, and $\mathrm{C}$ within the interior of the container). Each of the three thermocouples has two temperature sensors which measure temperatures at different levels at the locations $\mathrm{A}, \mathrm{B}$, and $\mathrm{C}$ in order to keep a recording of the temperature distribution during the reaction of a carbonaceous material and oxygen. At location A, sensors are located at levels 13 and $23 \mathrm{~cm}$ within the container, location B, 53 and $63 \mathrm{~cm}$, and location C, 33 and $43 \mathrm{~cm}$.

Oxygen is supplied and controlled at a fixed flow rate $(20 \mathrm{~mL} / \mathrm{min})$ by means of a flowmeter before being fed into a manifold attached below the lid of the autoclave Table 1. The changes in temperature distributions are recorded by the data logger every minute over $24 \mathrm{~h}$. The Wits-CT Index uses the total carbon content and the temperature differences due to the reaction with oxygen to predict the spontaneous combustion liability. According to Onifade et al. (2018), coals and coal-shales with a spontaneous combustion liability index below 2.5 are considered to be less reactive, $2.5-5$ moderately reactive, 5-7.5 reactive, and $>7.5$ are considered to be highly liable to spontaneous combustion. An illustration of the experimental setup is indicated in Fig. 4. The index is calculated from the formula in Eq. 2.

Wits-CT index $=\left(T_{\mathrm{M}} / 24+T_{\mathrm{R}}\right) \times \% \mathrm{C}_{\mathrm{ad}}$

where, $T_{\mathrm{M}}$ is the difference between the sum of maximum temperatures of each thermocouple inside the equipment and the room temperature $\left(22{ }^{\circ} \mathrm{C}\right), T_{\mathrm{R}}$ is the difference between the maximum temperature and the initial temperature during oxidation reaction in degree Celsius, $\% \mathrm{C}_{\mathrm{ad}}$ is the air-dried percentage of carbon content of the sample, $x$ is the multiplication sign and 24 is the duration of the test $(24 \mathrm{~h})$ and it is constant.

\section{Results and discussion}

\subsection{Statistical analysis}

The results for characterisation tests (proximate, elemental and petrographic analysis) and spontaneous combustion tests (the Wits-Ehac Index and the Wits-CT Index) carried out on the samples are presented in Tables 2, 3, 4, 5 and 6 respectively. The evaluation of coal and coal-shales intrinsic factors affecting spontaneous combustion was at first based on data obtained from the spontaneous combustion liability tests and the intrinsic properties as determined in the laboratory. It is appropriate to group the data into dependent (the Wits-Ehac Index and the Wits-CT Index) and independent (intrinsic properties) variables in order to make the analyses meaningful. The observed temperatures values of spontaneous combustion tests are dependent on the coal and coal-shale properties, coalforming elements and coal structure. Hence, the statistical 
analysis was carried out by correlating the samples intrinsic properties and spontaneous combustion liability indices. The range value (Table 1) is the value of the independent variables from the lowest to the highest. The R-squared value is a statistical tool which can either carry out hypothesis testing or predict future result on the basis of related information. It provides a measure of how well observed outcomes are reproduced by a model on the basis of the proportion of total variation of outcomes described by the model (Draper and Smith 1998; Glant 1990). The higher the R-squared value, the better the fit is. In statistics, the correlation coefficient measures the strength and direction of a linear relationship between two variables (dependent and independent variables) on a scatter plot (Deborah 2016; Stigler 1989). The range of values for the correlation coefficient is -1.0 to 1.0 and it is a representation of the linear interdependence of two variables or sets of data. The correlation coefficients were obtained using the data analysis in MS Excel. A correlation coefficient of -1.0 indicates a perfect negative correlation, while a correlation of 1.0 indicates a perfect positive correlation. A correlation coefficient of 1.0 indicates a perfect positive relationship between two variables. i.e. for a positive increase in one variable, there is also a positive increase in the second. A correlation coefficient of -1.0 indicates a perfect negative relationship between the two variables. i.e. the variables move in opposite directions, for a positive increase in one variable, there is a decrease in the second variable. A zero correlation means that for every increase, there is no positive or negative increase (i.e. the two are not related). The R-squared values and the correlation coefficients were used to measure the trends and any significant relationships between the intrinsic properties and the WitsEhac Index and Wits-CT Index. The overall database involved the spontaneous combustion test results and intrinsic properties of 14 coals and 14 coal-shales in order to determine the factors affecting spontaneous combustion. The study interpreted the linear relationship between the intrinsic properties and spontaneous combustion liability index based on the set criterion (Table 1).

The criterion is established based on the strength and directions of a linear relationship between the intrinsic properties and spontaneous combustion liability index on a scatter plot. Statistically correlations of +1 or -1 are expected, however, this is not possible due to the use of real dataset from experimental tests, and real data are never perfect to get a perfect correlation coefficient (Deborah 2016). Since the results of the real data is expected to determine how close is close enough to indicate a strong, moderate or weak linear relationship, this necessitated the need to interpret the correlation coefficient values, classify and find how close they are using the set criterion (Table 1). Given that the correlation coefficient measures the degree to which how two variables vary together, establishing a criterion means whether each intrinsic property and spontaneous combustion liability index vary strongly, moderately or weakly and if it is a positive or negative relationship. The higher the correlation coefficient, the stronger the relationship is (higher correlation coefficients means a better prediction).

\subsection{Linear regression analysis}

The results of the characterisation tests were correlated with the spontaneous combustion liability indices (WitsEhac Index and the Wits-CT) statistically. Data from the experimental tests using the linear regression analysis is given in the Tables 2, 3, 4, 5 and 6 and the values in brackets are in negative sign.

As a preliminary step, the experimental data was analysed using statistical methods to ascertain whether any of the parameters were linearly related to the oxidation potential. The dataset was divided into dependent and independent variables in order to establish trends and relationships. The correlation coefficients between the independent and dependent variables are seen in Tables 2, $3,4,5$ and 6 . The linear regression analysis was used to identify if there are better linear relationships between dependent and independent variables. It was found that each factor has an influence towards spontaneous combustion based on their relationships.

The statistical analysis demonstrated the better linear relationship between the dependent and independent variables in most cases based on the R-squared values (Figs. 5, $6,7,8,9,10,11,12,13,14,15,16)$ and correlation coefficients obtained. The higher correlation coefficients obtained from the data sets suggest that this may be the best way to minimize the overriding effect of the various coals and coal-shales on analysis of the general oxidation trends. Thus, obtaining a result which may be an indication of spontaneous combustion liability of certain carbonaceous materials. It is well-known that carbonaceous materials behaves differently when subjected to similar atmospheric conditions due to differences in their physical and chemical properties. The analysis of variable pairs (moisture/WitsEhac Index; moisture/Wits-CT Index; volatile matter/WitsEhac Index; volatile matter/Wits-CT Index; ash/Wits-Ehac Index; ash/Wits-CT Index and etc.) demonstrated uniform trends, i.e. the oxidation trend increases with increasing volatile matter, carbon, hydrogen, etc. and decreases with increasing ash and mineral matter, etc. for both coal and coal-shale samples. Working with carbonaceous materials having similar rank make it difficult to establish significant relationships between the petrographic composition and spontaneous combustion liability as was expected before regression. This is in-line with the study reported by Eroglu 
(1992). Few significant relationships were found between the spontaneous combustion liability indices and petrographic composition (total vitrinite, total inertinite and total liptinite) from the statistical analysis. However, it was decided to investigate the relationship between the various

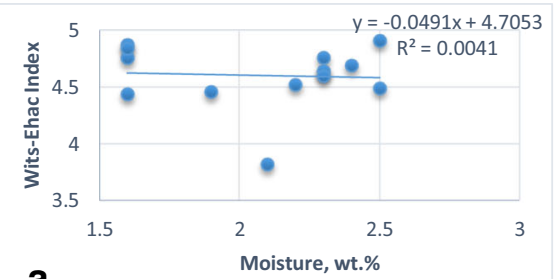

a
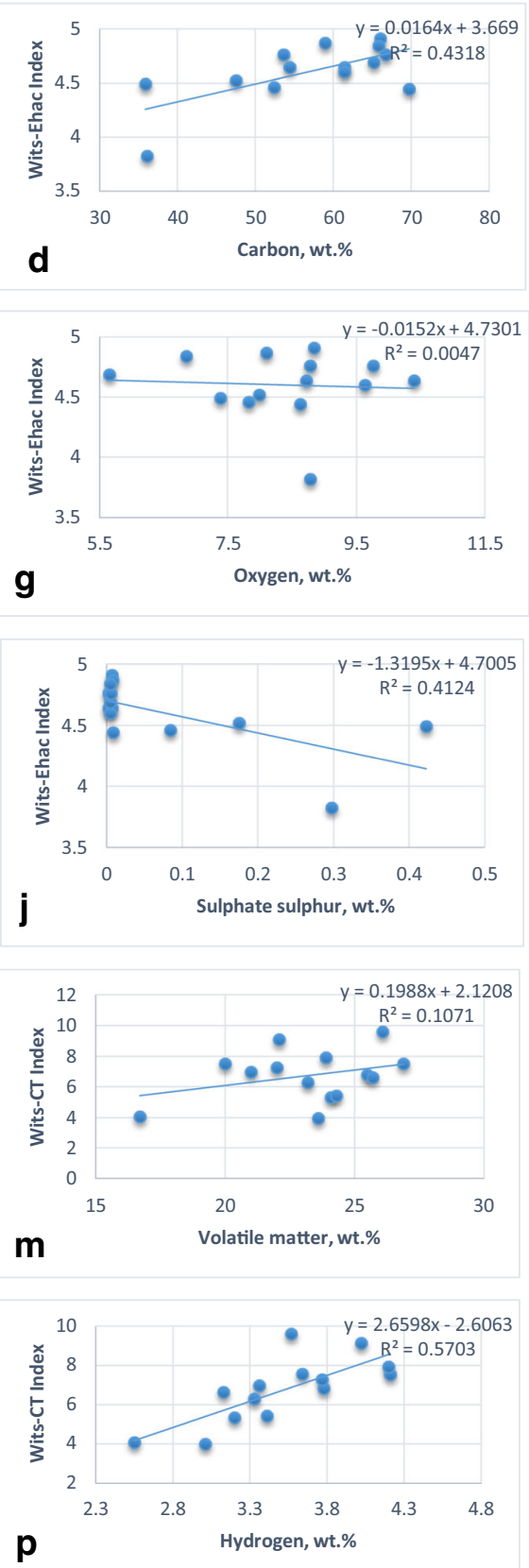
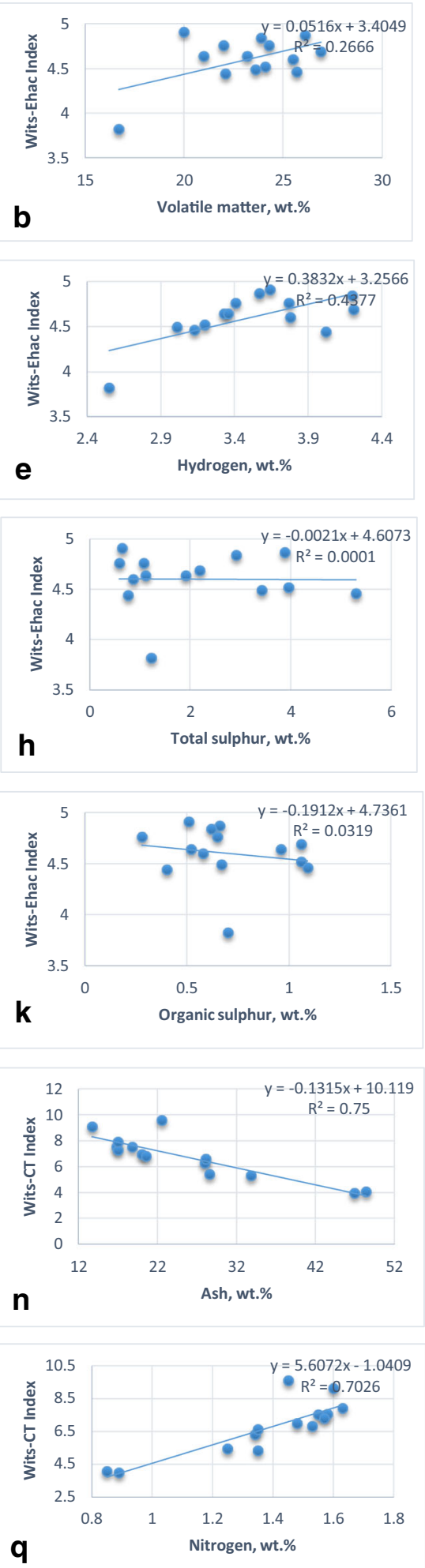
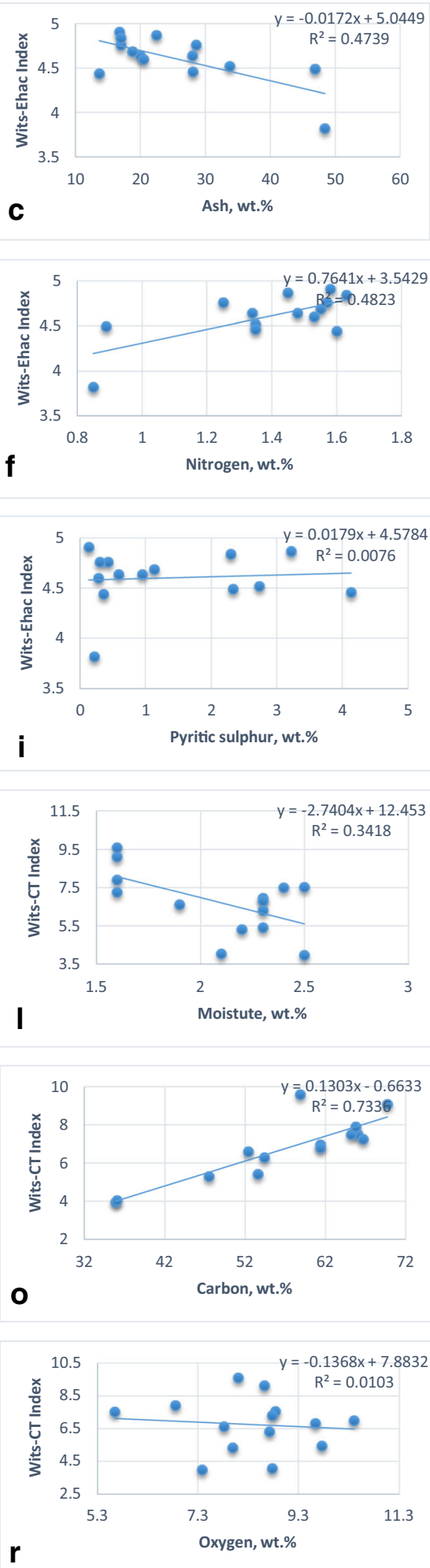

Fig. 5 Influence of proximate and ultimate analysis on spontaneous combustion of coals 

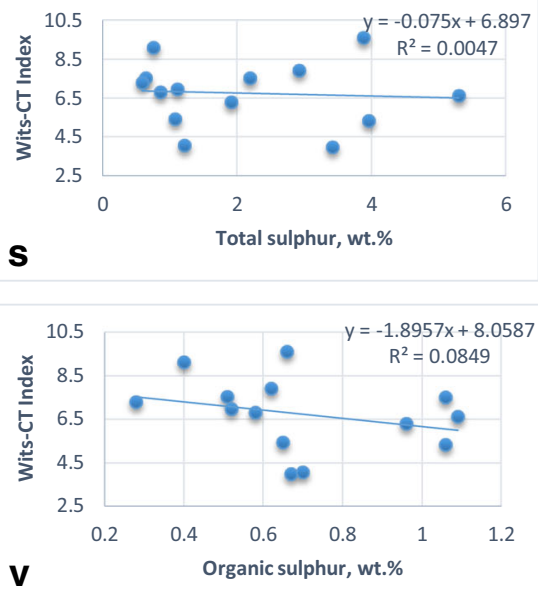
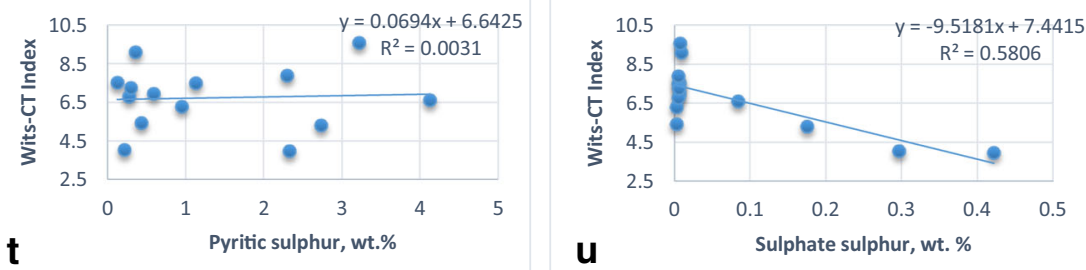

Fig. 5 continued

constituents of each maceral group on spontaneous combustion liability results.

From Tables 2, 3, 4, 5, 6 and 7, based on the criterion set, it was found that contents of volatile matter, 0.5164; ash, -0.6884; carbon, 0.6572; hydrogen, 0.6616; nitrogen, 0.6945; sulphate sulphur, 0.6422; and inertinite macerals [fusinite, 0.5663] with strong effect size are parameters affecting spontaneous combustion liability of coals. Furthermore, it was found that contents of moisture, 0.7715; volatile matter, 0.6389 ; ash, -0.8352 ; carbon, 0.7962 ; hydrogen, 0.5795 ; nitrogen, 0.6446 ; total sulphur, 0.5791 ; and its forms [pyritic, 0.5704; sulphate, 0.5365; and organic sulphur, 0.5933], total inertinite, 0.7360; and its constituents [fusinite, 0.5898; total semifusinite, 0.7776; secretinite, 0.6003; and total inertodetrinite, 0.7749] total maceral, 0.7653 ; and mineral matter, -0.7653 with strong effect size are factors affecting spontaneous combustion liability of coal-shales. The linear regression analysis shows that both liability indices show better linear relationships with some of the intrinsic properties and thus, identifies the major intrinsic factors affecting spontaneous combustion liability. Previous studies by Falcon (2004); Gouws and Wade (1989a); Sahu et al. 2005; Kaymacki and Didari (2002); and Nimaje and Tripathy (2016) indicated that intrinsic properties are a measure of spontaneous combustion liability. The effects of coals and coal-shales intrinsic properties on spontaneous combustion liability are shown in Figs. 5, 6, 7, 8, 9, 10, 11, 12, 13, 14, 15 and 16 using linear regression analysis.

\subsection{Effects of intrinsic properties on spontaneous combustion of coal and coal-shale samples}

Figures 51 and 6a show the effect of moisture content on the spontaneous combustion liability of the coals obtained from the linear regression analysis. The results indicated a negative correlation for the coals and a positive correlation for the coal-shales. As the correlation displays R-squared of 0.3418 for coals, it shows that the linear model has a moderate strength. It is different for the coal-shales. Here the R-squared is higher, 0.5952, than the coals. This means the coal-shales have a strong effect size.

The R-squared value for volatile matter is considered as 0.2666 for coals and 0.4763 for coal-shales (Figs. 5b and $6 \mathrm{~m})$. This is an indication that both coals and coal-shales have a moderate effect size. There is a positive relationship between volatile matter and spontaneous combustion liability index for both cases. This means that as the volatile matter increases, the oxidation capacity of coals and coalsshales is more likely to increase in general. This is in-line with the study reported on coal by Singh and Demirbilek (1987).

There is a negative relationship between the ash content and spontaneous combustion liability index for both coals and coal-shales. This means that as ash content increases, the spontaneous combustion liability decreases. This is inline with the study reported on coal by Beamish and Blazak (2005), Singh and Demirbilek (1987). The relationship between the ash content and spontaneous combustion liability index seems to be strong. The R-squared value is 0.75 for coals and 0.8926 for coal-shales (Figs. $5 n$ and $6 n$ ). The value for coals and coal-shales have a strong effect size. The decreasing ash content affects the oxidation potential by causing a relatively high spontaneous combustion liability for both coals and coal-shales analysed. This is in-line with the studies reported on coal by Beamish and Arisoy (2008), Humphreys et al. (1981), Panigrahi and Sahu (2004); Smith et al. (1988).

The R-squared value for the carbon content is 0.7336 for coals and 0.9273 for coal-shales (Figs. 5o and 6o). The 

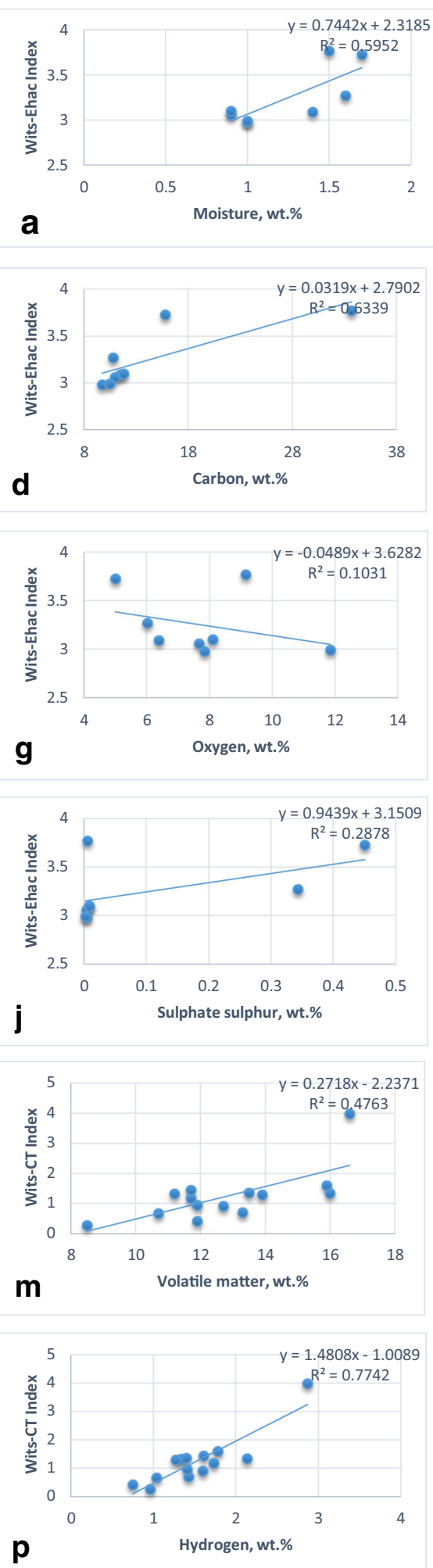
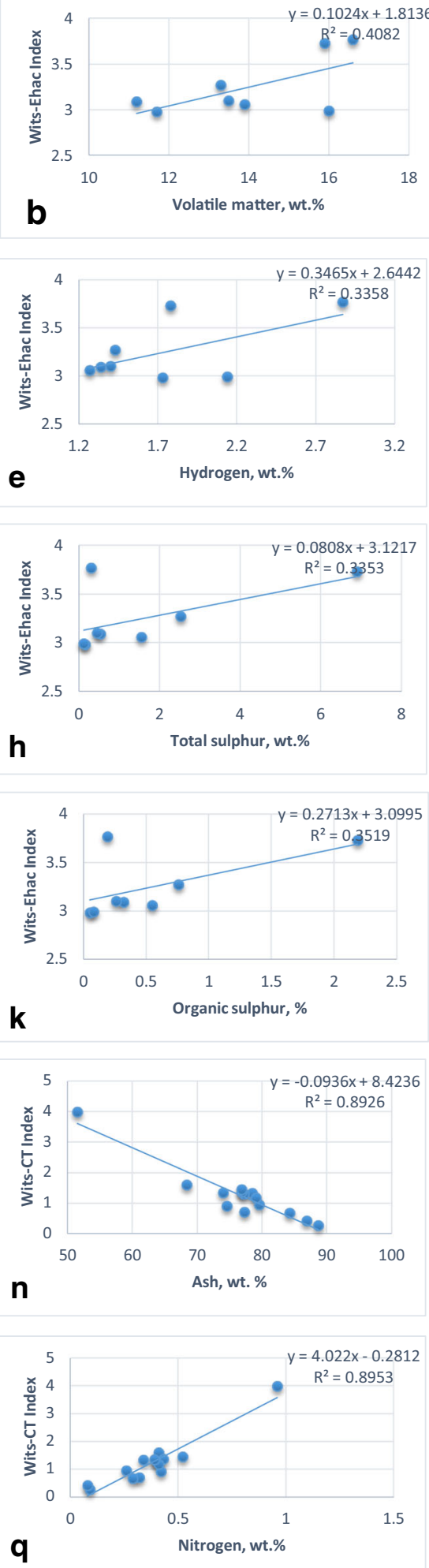

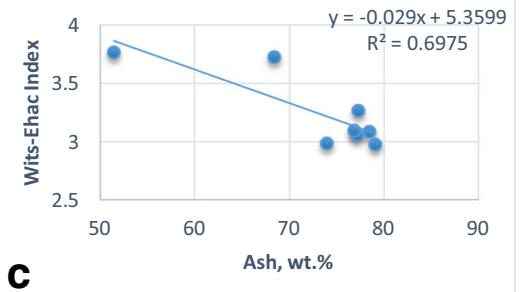

C
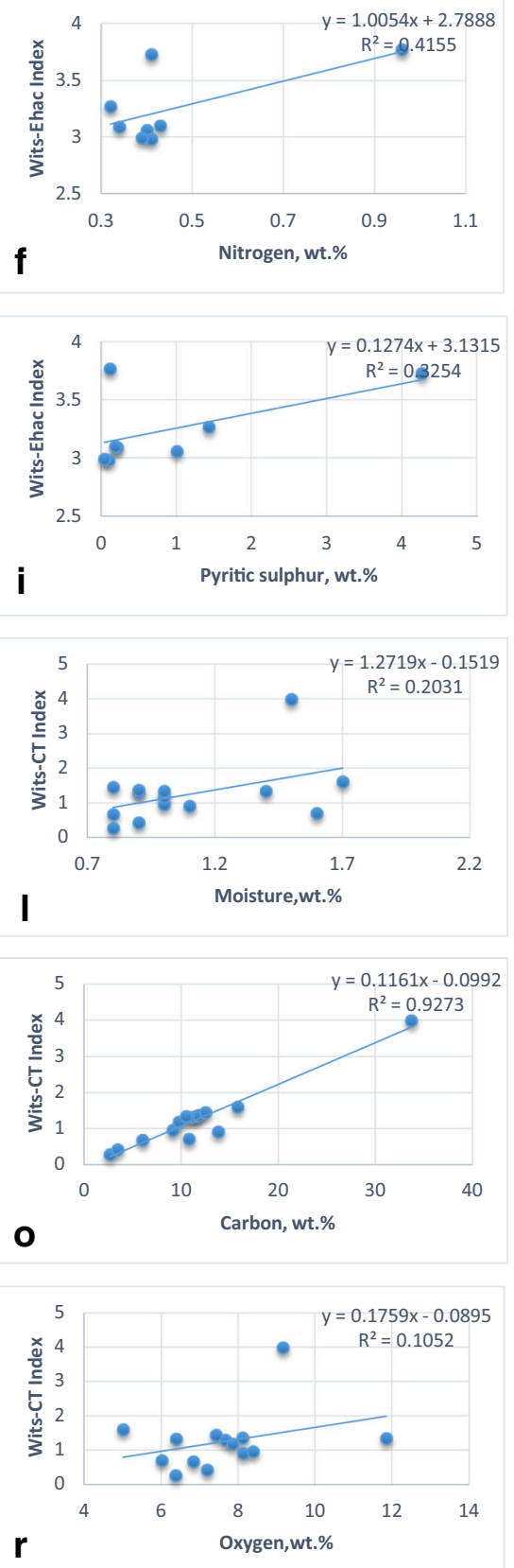

Fig. 6 Influence of proximate and ultimate analysis on sponatneous combustion of coal-shales 


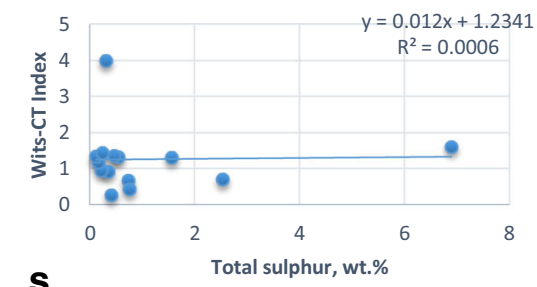

$\mathbf{S}$

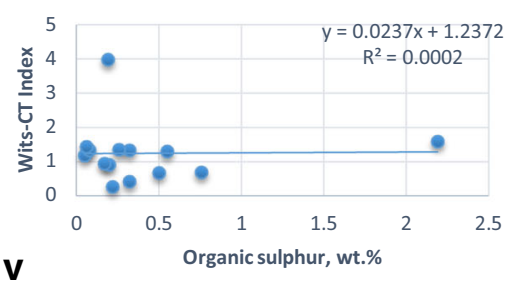

Fig. 6 continued
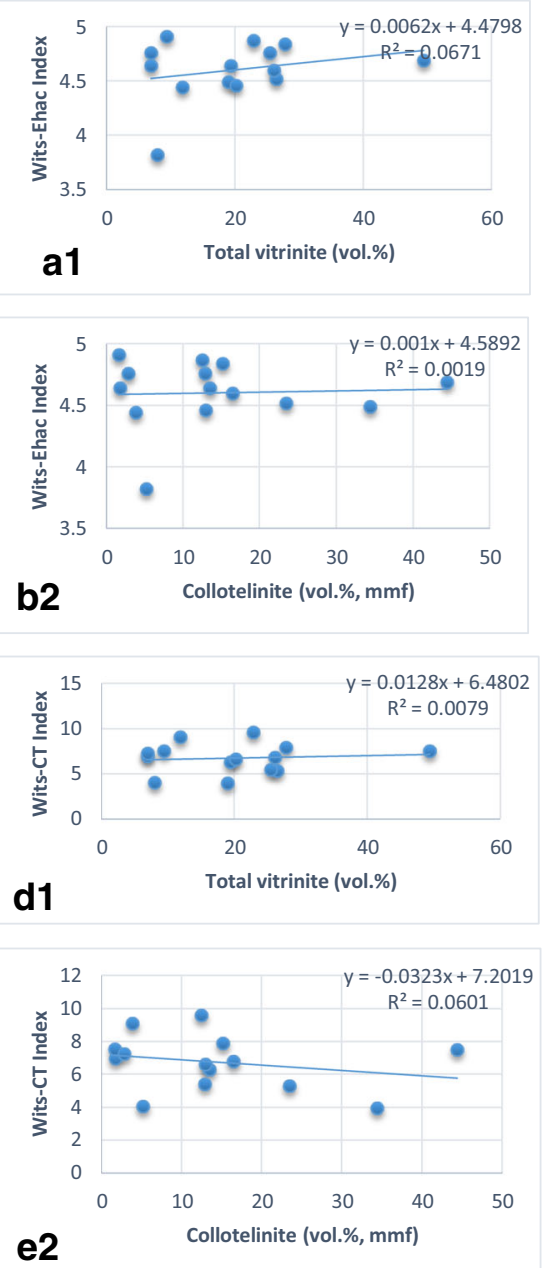
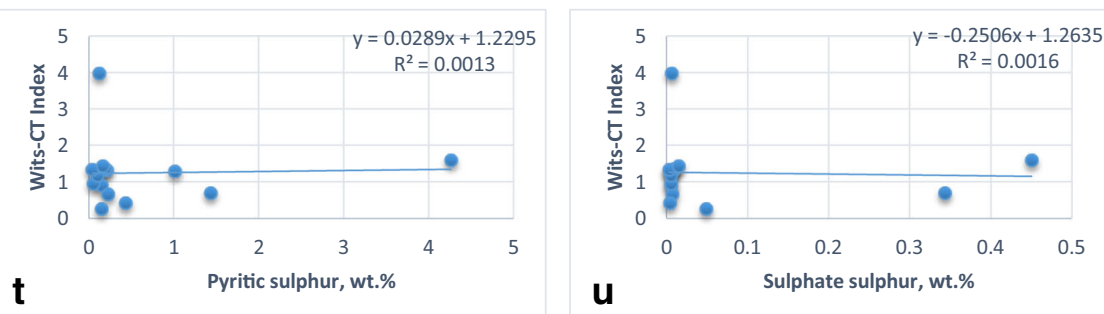

$\mathbf{u}$
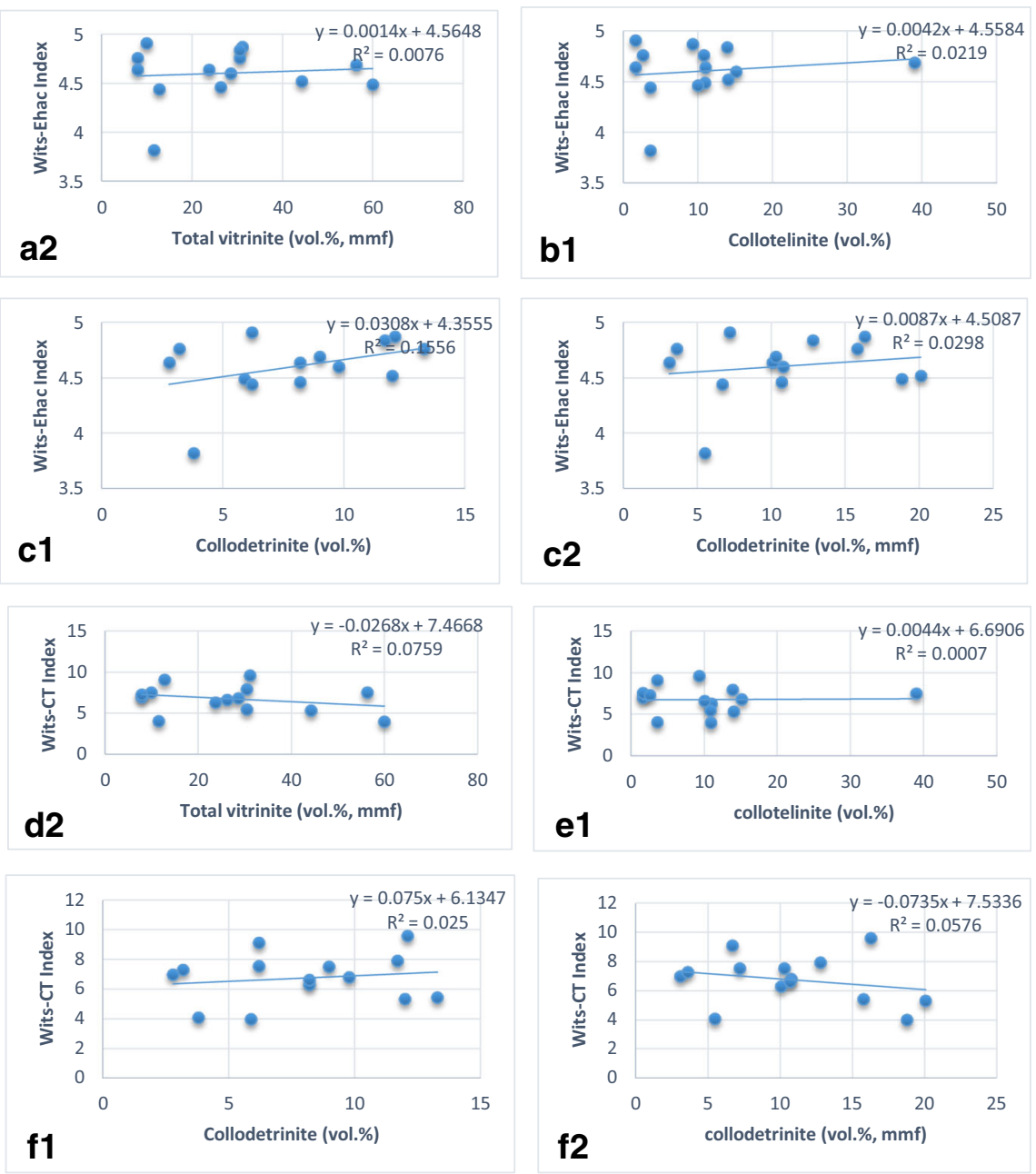

Fig. 7 Influence of vitrinite and its group on spontaneous combustion of coals 

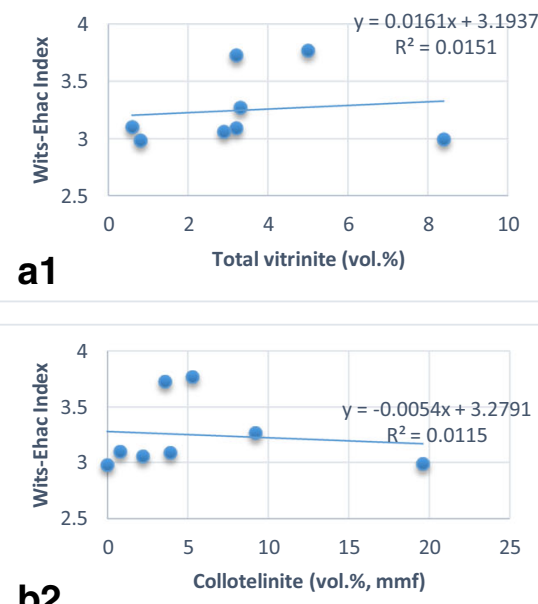

b2
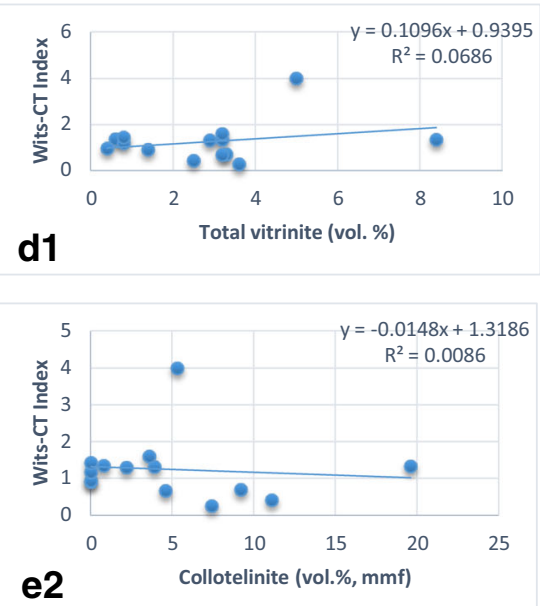
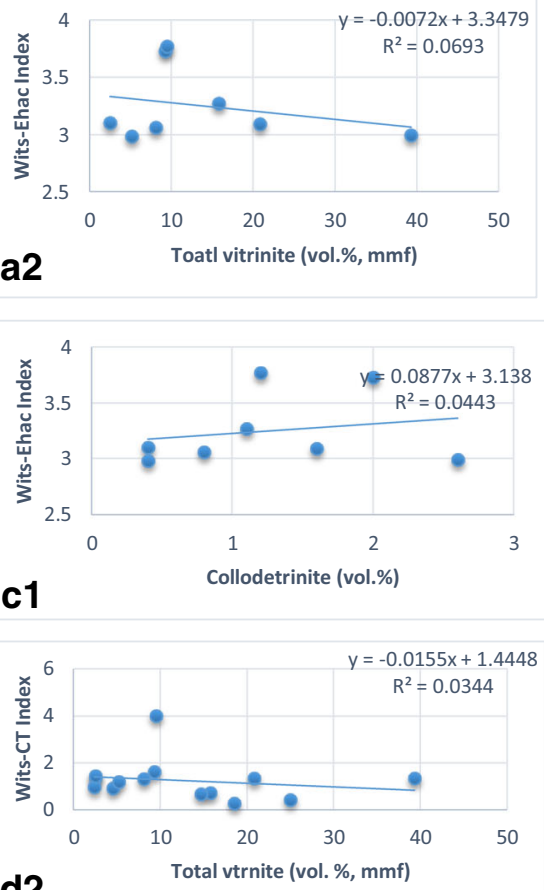

d2

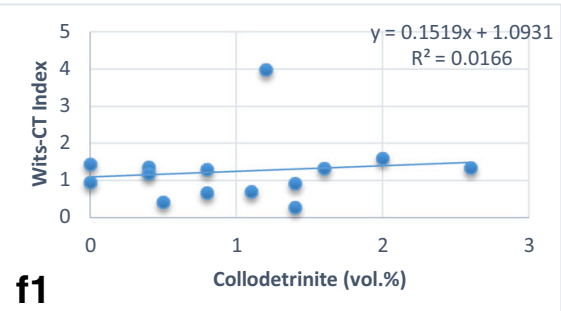

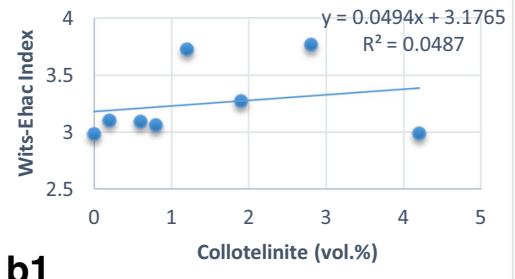

b1
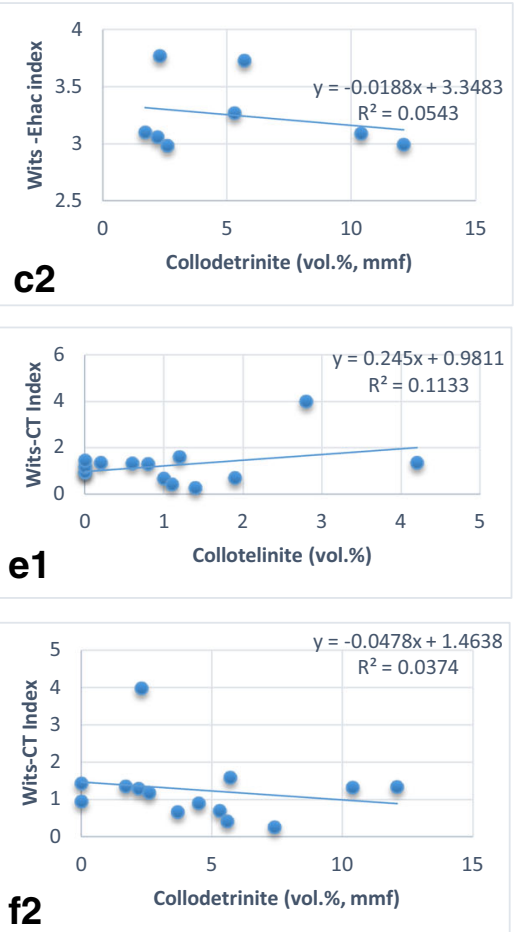

Fig. 8 Influence of vitrinite and its group on spontaneous combustion of coal-shales

relationship between carbon content and spontaneous combustion liability index for coals and coal-shales seems to be strong. The value for coals and coal-shales have a strong effect size. There is a positive relationship between the carbon content and spontaneous combustion liability index for both the coals and coal-shales. This means that as the carbon content increases, the oxidation capacity of coals and coal-shales are more likely to increase in general. The increasing carbon content affects the oxidation potential of both coals and coal-shales by causing a relatively high spontaneous combustion liability.

There is a positive relationship between the hydrogen content and spontaneous combustion liability index for both the coals and coal-shales. This means that as the hydrogen content increases, the oxidation capacity of coals and coal-shales is more likely to increase in general. The increasing hydrogen content affects the oxidation potential of both coals and coal-shales by causing a relatively high spontaneous combustion liability. The R-squared value for the hydrogen content is 0.5703 for coals and 0.7742 for coal-shales (Figs. 5p and 6p). The relationship between the hydrogen content and spontaneous combustion liability index for coals and coal-shales are a strong positive.

The R-squared value for the nitrogen content is 0.7026 for coals and 0.8953 for coal-shales (Figs. 5q and 6q). The relationship between the nitrogen content and spontaneous combustion liability index for coals and coal-shales are a strong positive. This means that as the nitrogen content increases, the oxidation potential of coals and coal-shales is more likely to increase in general.

Figures $5 r$ and $6 r$ show the effect of calculated oxygen on the spontaneous combustion liability of the coals and coal-shales obtained from the linear regression analysis. The evaluation of the calculated oxygen indicated a negative correlation for the coals and a positive correlation for the coal-shales. As the correlation (Fig. 5r) displays R-squared of 0.0103 for coals, it shows that the linear model does not fit well. It is different for the coal-shales. 

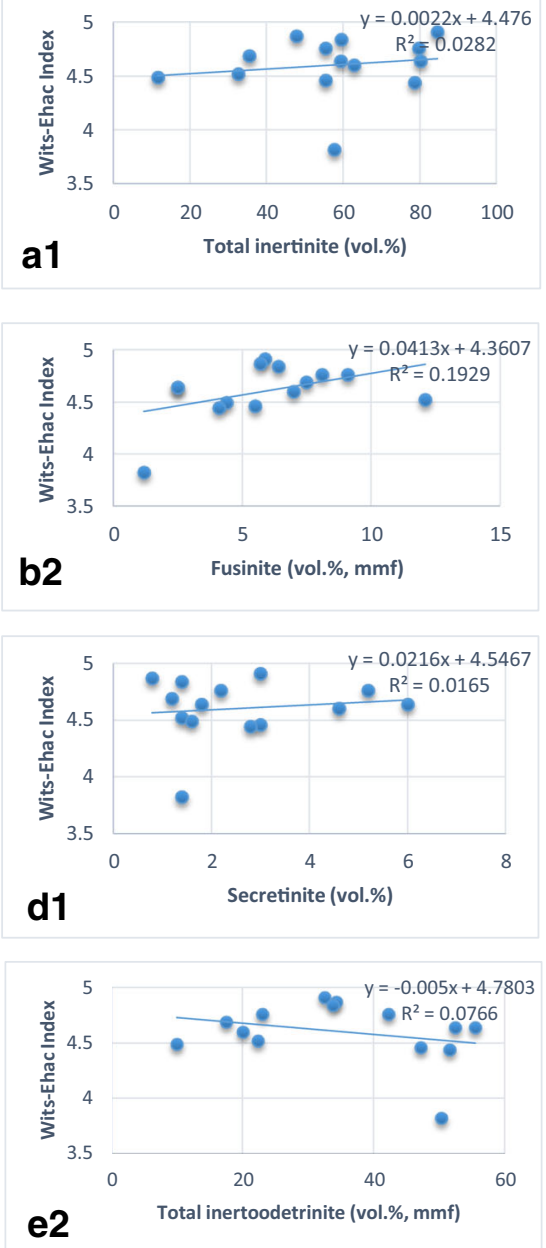
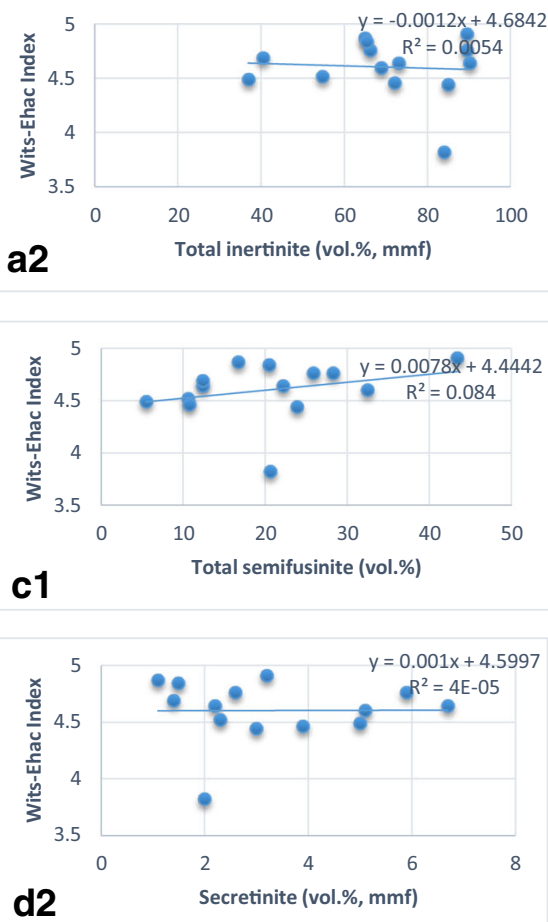

d2

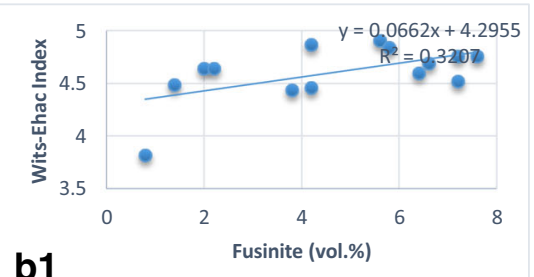

b1
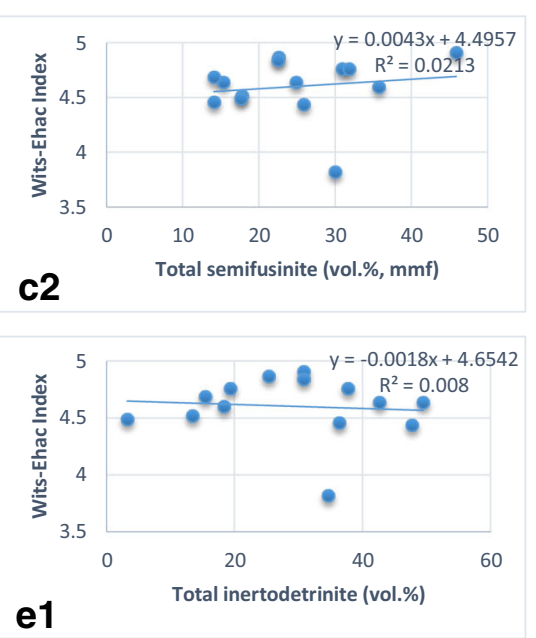

Fig. 9 Influence of inertinite and its group on spontaneous combustion of coals

Here, the R-squared is a bit higher, 0.1052, than the coals. The coals and coal-shales have a very weak effect size.

The evaluation of the total sulphur indicated a negative correlation for the coals and a positive correlation for the coal-shales (Figs. 5h and 6h). This is in-line with the study reported on coal by Singh and Demirbilek, (1987). As the correlation displays an R-squared value of 0.0047 for coals (Fig. 5h), it shows that the linear model does not fit well. It is different for the coal-shales. Here, the R-squared value is a bit higher, 0.3353 , than the coals. The value of coals has a very weak effect size, while the value for coal-shales have a moderate effect size.

The R-squared value for pyritic sulphur is 0.0076 for coals and 0.3254 for coal-shales (Figs. 5i and 6i). This is in-line with the study reported on coal by Singh and Demirbilek (1987). The evaluation of the pyritic sulphur indicated a positive correlation coefficient for both the coals and coal-shales. This means that as the pyritic sulphur increases, the oxidation potential of coals and coalshales is more likely to increase in general. The scatter plots show that the corresponding spontaneous combustion liability values display a wide variation. The value for coals have a very weak effect size, while coal-shales have a moderate effect size. The linear regression analysis was quite similar to those obtained from the total sulphur content data.

The R-squared value for sulphate sulphur is 0.5806 for coals and 0.2878 for coal-shales (Figs. $5 u$ and $6 \mathrm{j}$ ). The value for coals have a strong effect size, while the value for coal-shales have a moderate effect size. The evaluation of the sulphate sulphur indicated a negative correlation for the coals and a positive correlation for the coal-shales. This means that as sulphate sulphur increases for the coals, the spontaneous combustion liability decreases, while for the coal-shales as the pyritic sulphur increases, the oxidation potential is more likely to increase in general. This is inline with the study reported on coal by Singh and Demirbilek (1987). The scatter plots show that the corresponding spontaneous combustion liability values display a wide 

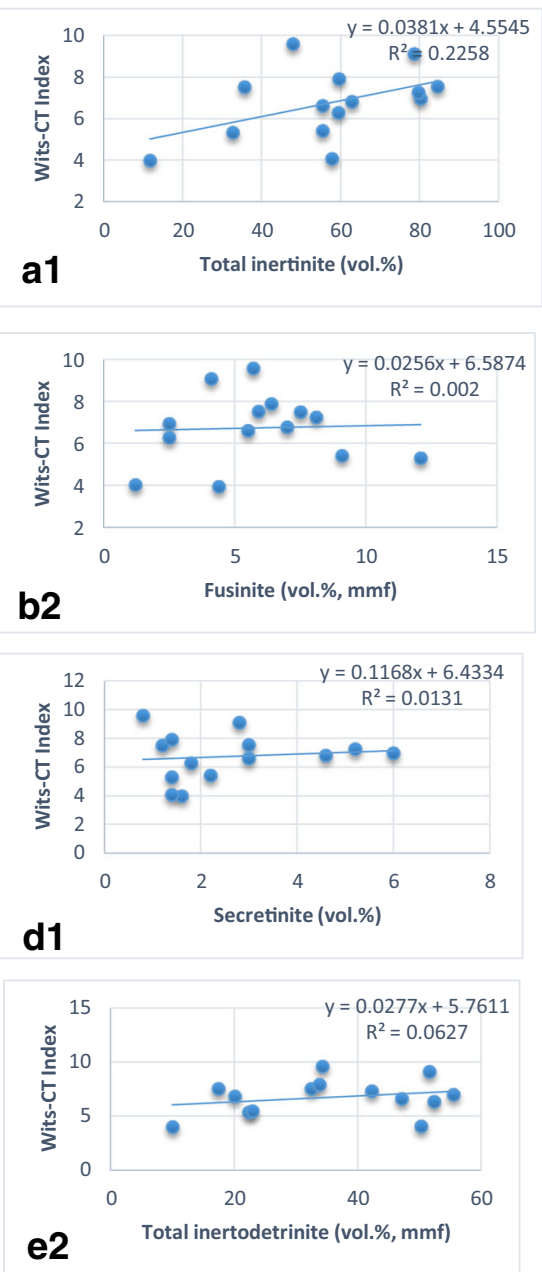
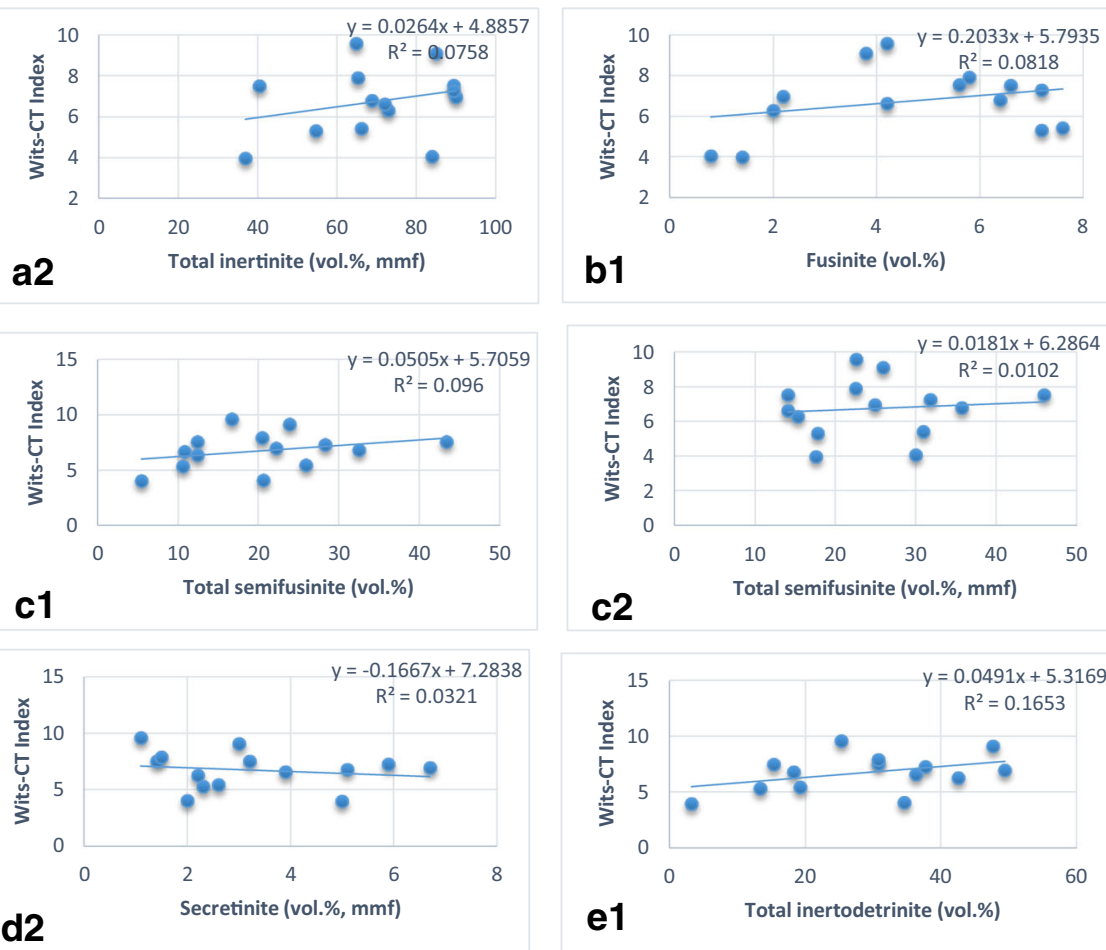

b1
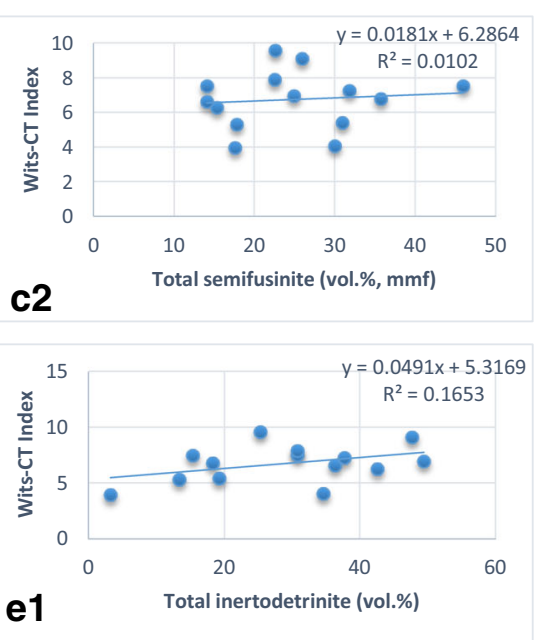

Fig. 10 Influence of inertinite and its group on spontaneous combustion of coals

variation which is quite similar to that obtained from the total sulphur and pyritic sulphur data.

The evaluation of the organic sulphur indicated a negative correlation for the coals and a positive correlation for the coal-shales. This means that as organic sulphur increases for the coals, the spontaneous combustion liability decreases, while for the coal-shales as the organic sulphur increases, the oxidation potential is more likely to increase in general. This is in-line with the study reported on coal by Singh and Demirbilek (1987). The R-squared value for organic sulphur is considered as 0.0849 for coals and 0.3519 for coal-shales (Figs. $5 \mathrm{v}$ and $6 \mathrm{k}$ ). The value for coals have a very weak effect size, while the value for coalshales have a moderate effect size.

The graphs of the major macerals (vitrinite, inertinite and liptinite) and spontaneous combustion liability index indicates that there may be relationships even though the $\mathrm{R}$-squared values and correlation coefficients are very weak in most cases. A similar study is reported by Eroglu (1992). The analysis showed that the relationships between the various maceral groups and the oxidation potential may be significant when the maceral constituents were unpacked either in the mineral matter free basis (mmf) or inclusive of mineral matter. The results of the linear regression analysis obtained indicated that the various maceral groups have either a positive or negative effect size (Figs. 7, 8, 9, 10, 11, 12, 13, 14, 15 16). It was found that the majority of the vitrinite and its group (collotelinite and collodetrinite) and liptinite and its group (sporinite) in both cases have a very weak effect size. Inertinite macerals (total inertodetrinite, total semifusinite, fusinite and secretinite) shows a better linear relationship to oxidation potential more than the vitrinite and liptinite macerals. The study indicated that the oxidation potential of coals and coal-shales may be influenced by the amount of each maceral composition. This is in-line with the studies reported on coal by (Falcon 1987; Scott and Glasspool 2007). Petrographically observable mineral matter in the coal-shales show a better linear relationship to oxidation potential than the coals (Figs. 14e and 16e). 

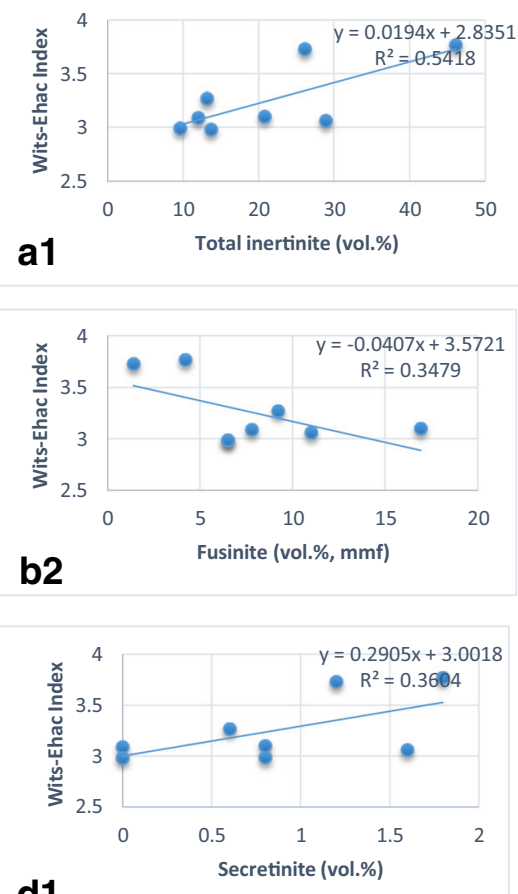

d1

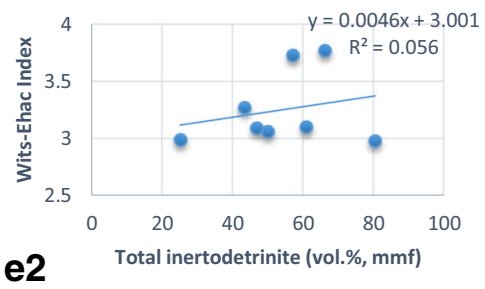

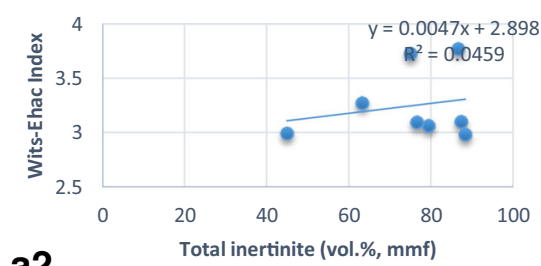

a2
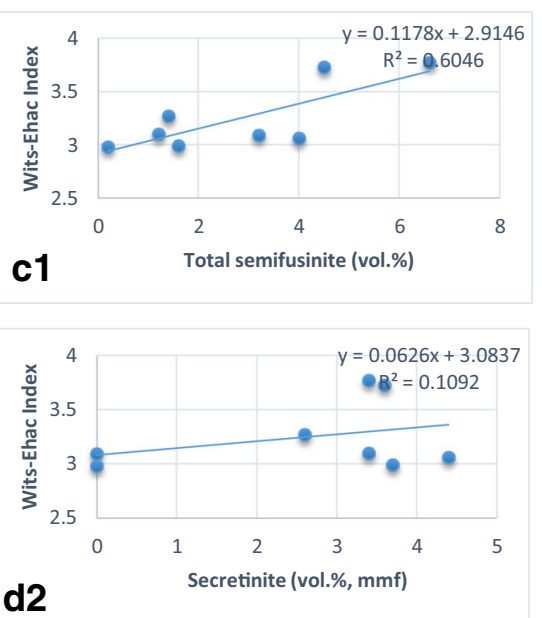

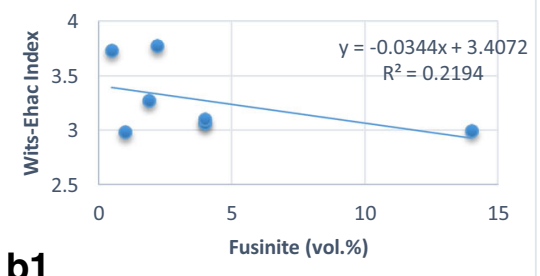

b1
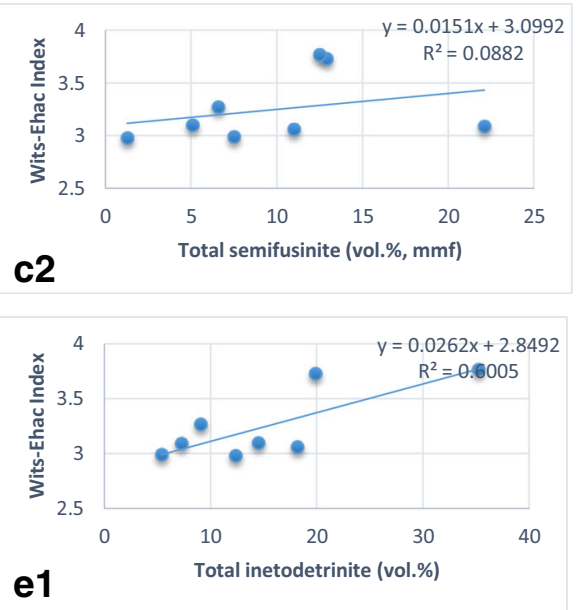

Fig. 11 Influence of inertinite and its group on spontaneous combustion of coal-shales

The study showed that there is a tendency of an increase in intrinsic properties such as moisture, volatile matter, ash, carbon, total sulphur, calculated oxygen, pyritic sulphur, organic sulphur, inertinite macerals and petrographically observable mineral matter in both coals and coal-shales but this seems to be more pronounced for coal-shales than for the coals, while coals seem to be more pronounced in terms of hydrogen, nitrogen and sulphate sulphur content than coal-shales. The inconsistencies (i.e. an independent variable with positive correlation coefficient with the WitsEhac Index may have a negative correlation with the WitsCT Index) in the correlation coefficients between the dependent (Wits-Ehac Index and Wits-CT Index) and independent (some of the intrinsic properties) variables cannot allow accurate determination of the major intrinsic properties affecting spontaneous combustion liability. Similar studies reported different correlation coefficients between some intrinsic factors (moisture, volatile matter, carbon, nitrogen, inertinite, vitrinite, exinite, total sulphur, pyritic sulphur, organic sulphur and calorific value) and the spontaneous combustion liability indices (Kaymakci and Didari 2002; Singh and Demirbilek 1987). The inconsistencies in the trend of correlation coefficients necessitated the developed models (Table 8). It is known that different methods have been used by previous studies to measure the spontaneous combustion liability of coals but no standard method has been considered the best in predicting spontaneous combustion liability (Stott 1980; Wade et al. 1987; Cliff et al. 1998; Beamish et al. 2001). This study investigated the factors affecting spontaneous combustion liability of coals and coal-shales using two different spontaneous combustion test methods (the Wits-Ehac Index and the Wits-CT Index) and evaluates the factor affecting these materials using statistical analysis. The two liability indices have been used to predict the spontaneous combustion liability of these materials and the results are in-line (Onifade and Genc 2018a, b). Limited studies have been conducted to establish relationships between two or more different spontaneous combustion liability indices and selected intrinsic properties (Singh and Demirbilek 

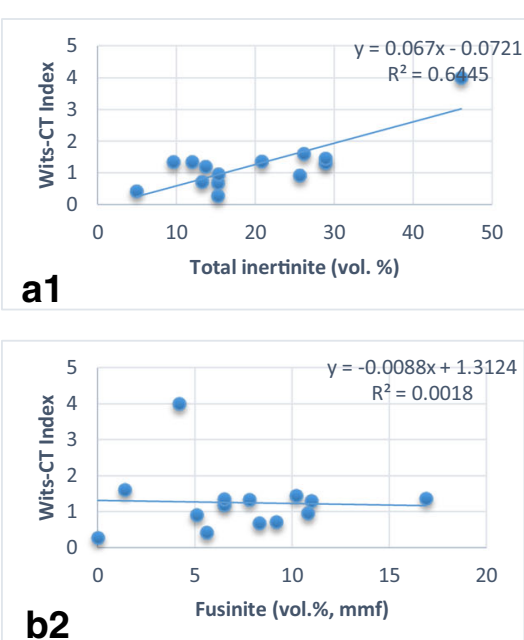

b2
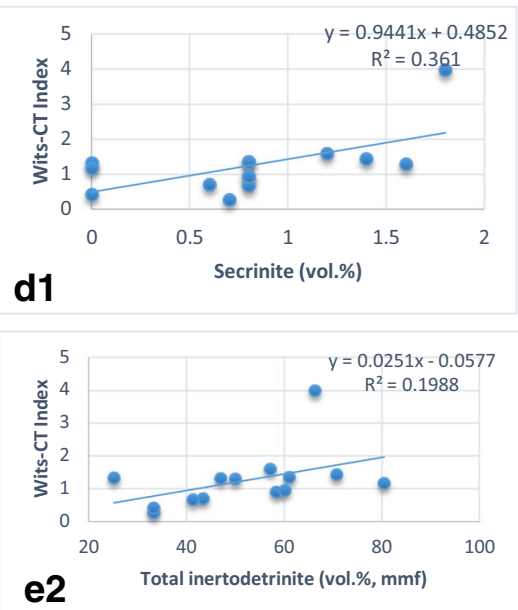
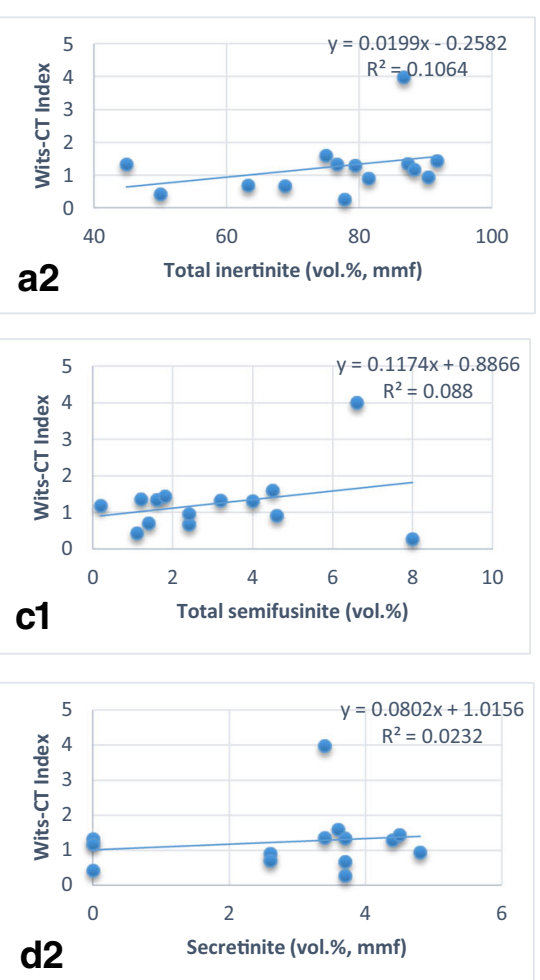
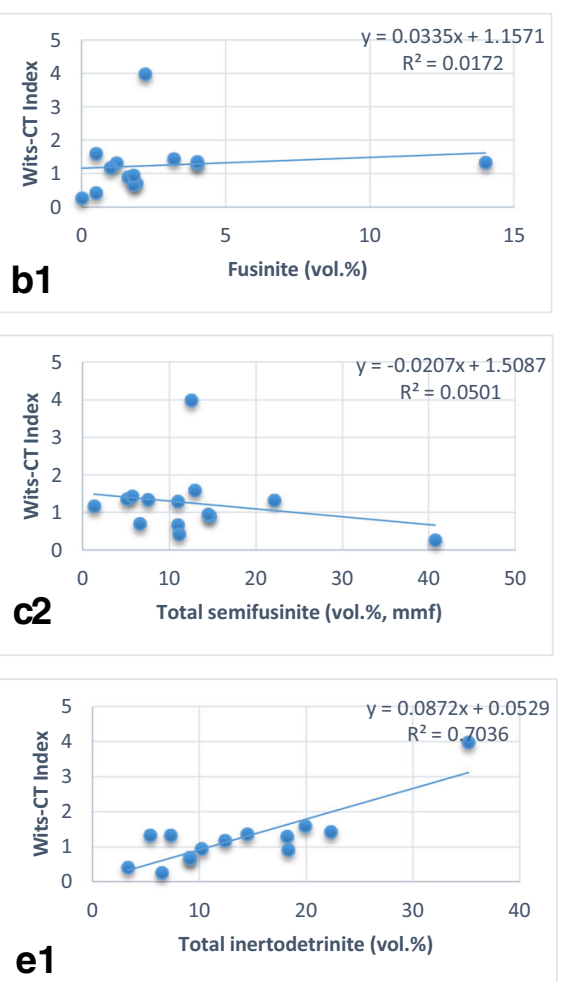

Fig. 12 Influence of inertinite and its group on spontaneous combustion of coal-shales

1987). This study established that some intrinsic properties show different linear trends (i.e. positive or negative correlation coefficients) with spontaneous combustion liability indices due to either the method of calculating the value of each index or the range of values assigned to represent each index for risk classification (see Wits-Ehac test and WitsCT test procedures).

\subsection{Multiple regression analysis}

The study indicated that the use of single variable equations obtained from the linear regression analysis to predict the spontaneous combustion liability of coals and coalshales is an unreliable method (Tables $2,3,4,5,6,7$ ). This is because some properties show different trends with the spontaneous combustion liability indices (i.e. similar property may be either positive or negative on the two liability indices which is not supposed to be so in a real sense). The lack of significant relationships between all the dependent and independent variables cannot allow separation of the main intrinsic properties influencing spontaneous combustion liability. It is more likely that the intrinsic properties have an influence on one another to some extent during low-temperature oxidation and this dependence of intrinsic properties determine the spontaneous combustion liability. This implies that the most favourable conditions for spontaneous combustion to occur likely depends on the interrelation of intrinsic properties. This necessitated the use of multiple regression to establish interrelationships between the intrinsic properties and spontaneous combustion liability results. The multiple regression analysis was used to derive the predictive models for spontaneous combustion liability of coals and coal-shales. The predictive models were derived by using 12 independent variables. The multiple regression analysis showed that some of the variables were highly correlated with other independent variables. The best model which provides the highest $\mathrm{R}$-squared values and correlation 

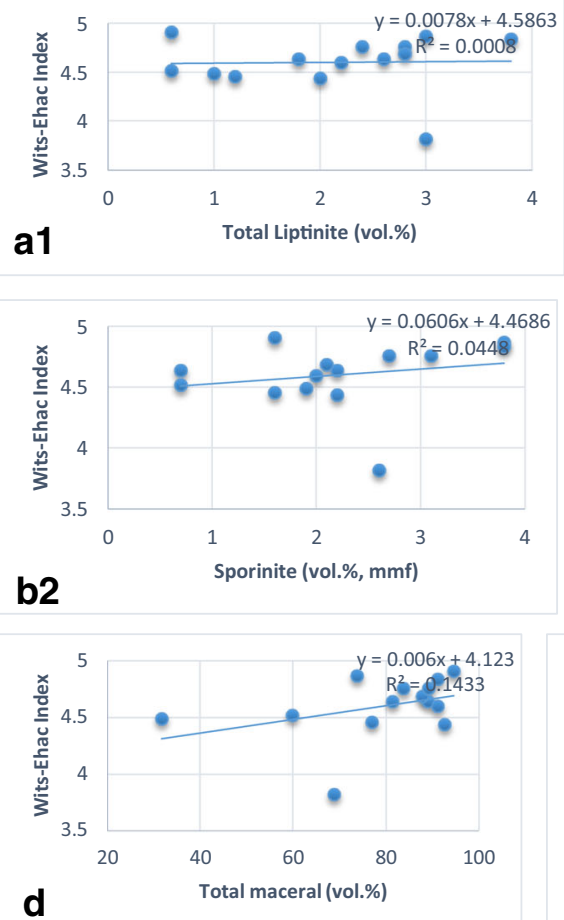

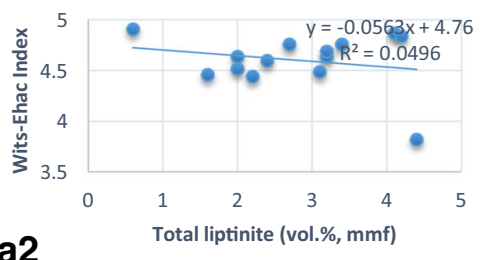

a2

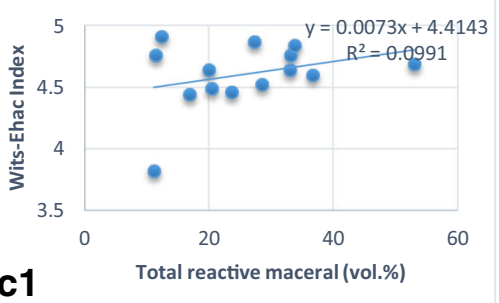

\section{c1}

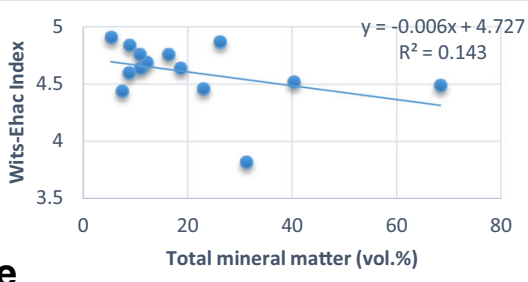

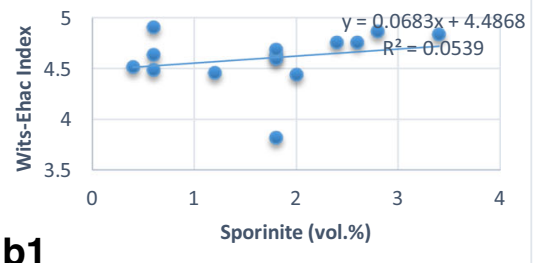

b1

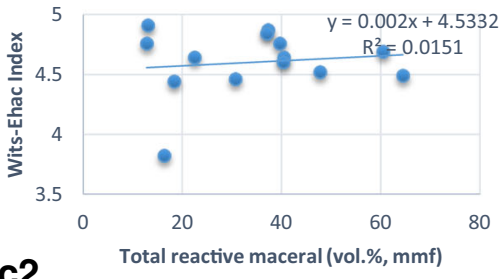

C2

Fig. 13 Influence of liptinite, other macerals, petrographically observable mineral matter on spontaneous combustion of coals
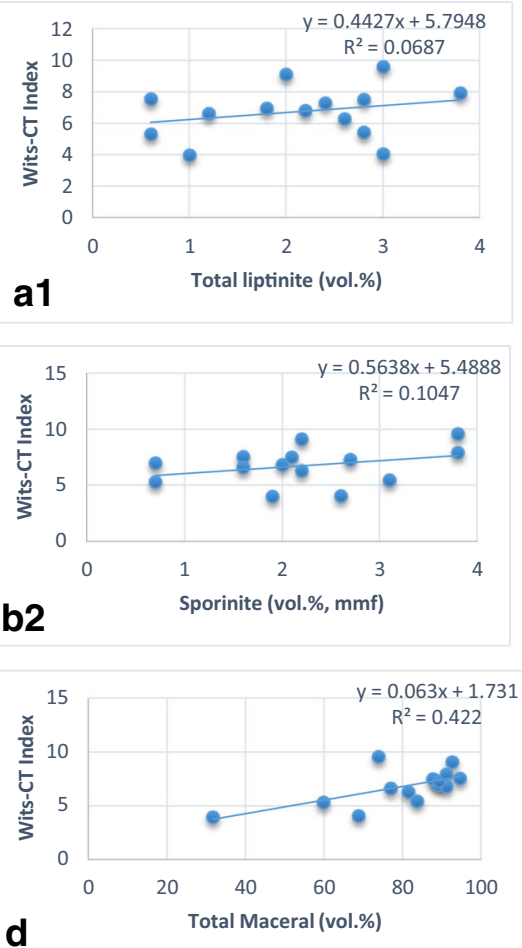
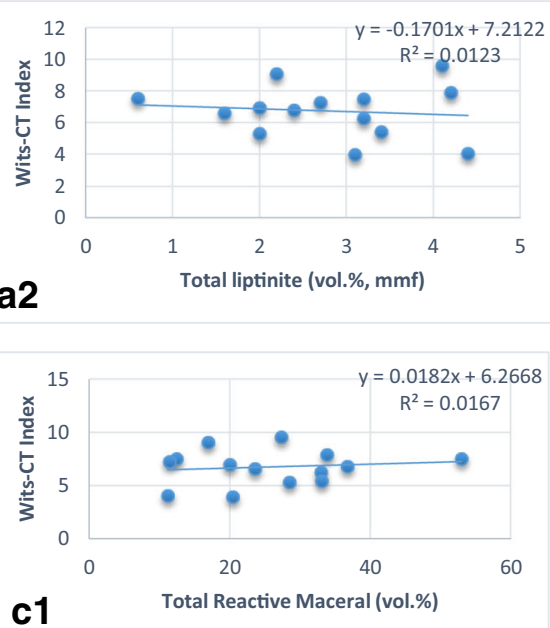

c1

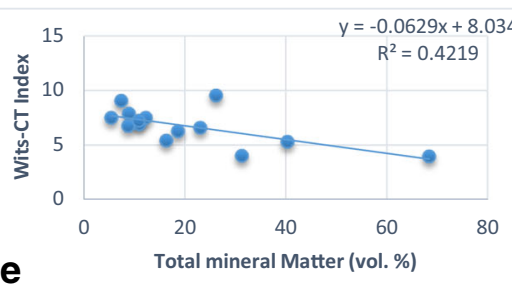

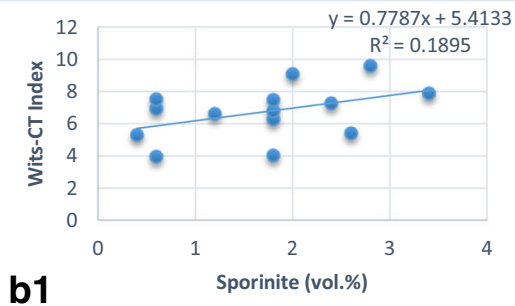

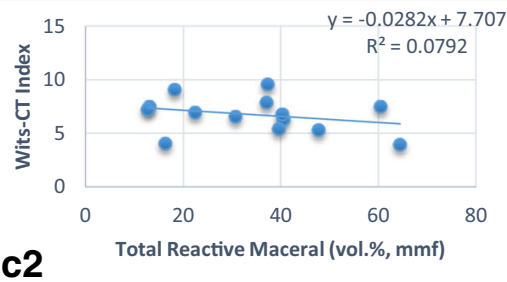

Fig. 14 Influence of liptinite, other macerals, petrographically observable mineral matter on spontaneous combustion of coals 

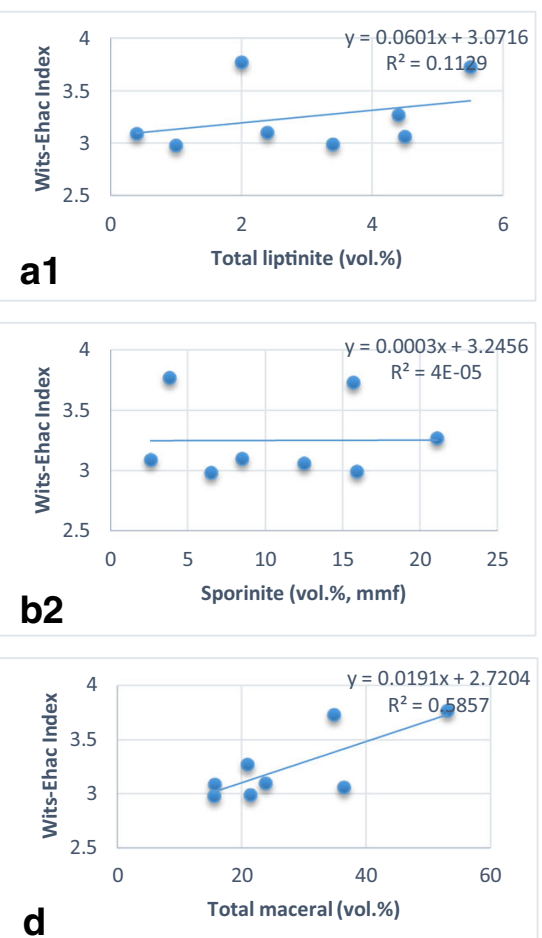
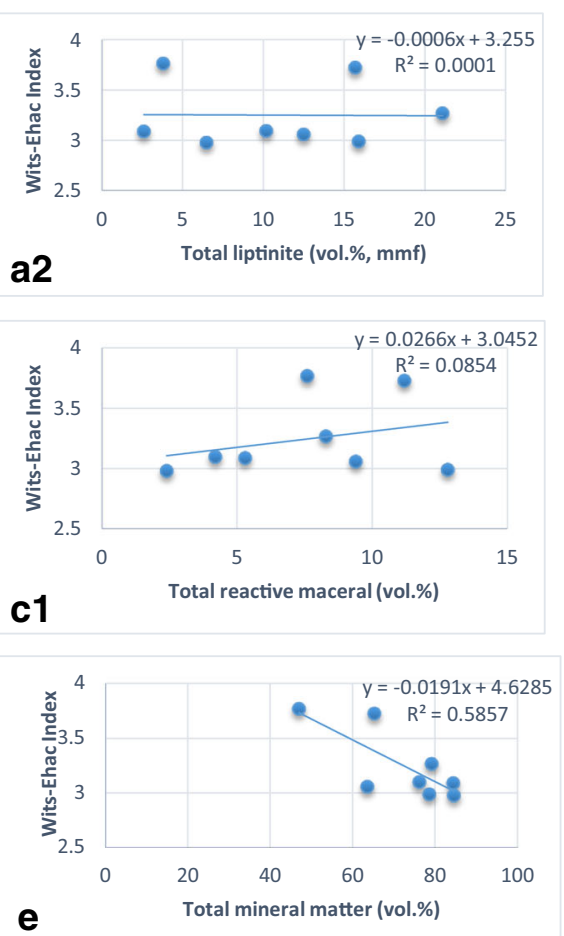
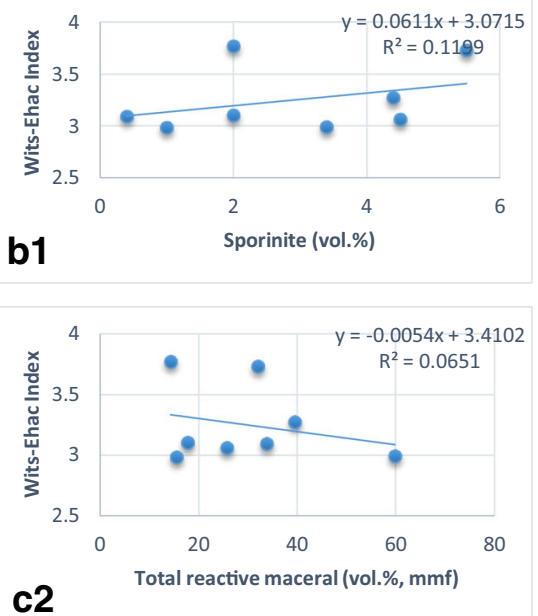

c2

Fig. 15 Influence of liptinite, other macerals and petrographically observable mineral matter on spontaneous combustion of coal-shales

coefficient and lowest standard error of estimate was found through some multiple regression calculations (Table 8).

A statistical standard form from the multiple regression results was selected to analyse and evaluate the influence of selected intrinsic properties on the spontaneous combustion liability of coals and coal-shales. This statistical approach indicated that the changes in spontaneous combustion liability index of coals and coal-shales may be due to an intrinsic parameter, while others are considered. The best prediction for spontaneous combustion liability of 14 coals and 14 coal-shales has been identified in the four models (Table 8). The developed models show that high correlation coefficients and the standard error of estimates values have been reduced to acceptable limits. The multiple regression analysis indicates that the Wits-Ehac Index and intrinsic properties show significant correlation coefficients of 0.939 and 0.998 , R-squared values of 0.882 and 0.997 , and low standard error of estimates of 0.336 and 0.094 for coals and coal-shales respectively. The Wits-CT Index with intrinsic properties shows significant correlation coefficients of 0.992 and 0.999 , R-squared values of 0.983 and 0.999 and higher standard error of estimate of 0.772 and 0.123 for coals and coal-shales respectively. It was found that the models developed for the Wits-Ehac Index gives lower R-squared values, coefficient of correlations and standard error of estimate while, the Wits-CT Index shows higher R-squared values and correlation coefficients and standard error of estimates than the Wits-Ehac Index in both cases. However, considering the index with higher $\mathrm{R}$-squared values and correlation coefficients, it was found that the Wits-CT Index is more suitable to predict the spontaneous combustion liability, while considering the index with low standard error of estimates, the Wits-Ehac Index is also suitable. Hence, multiple regression analysis on the experimental data indicates that the two liability indices can be used to obtain reliable results for spontaneous combustion prediction. Establishing a correlation between liability index and intrinsic properties for coals and coal-shales is essential for a better understanding of the role of coal-shales in spontaneous combustion. The models have shown that spontaneous combustion takes place due to the combined effect of different intrinsic factors.

\subsection{Validation of the models}

The results of the actual Wits-Ehac and Wits-CT Index for coals and coal-shales are presented in Tables 8 and 9.

The predicted spontaneous combustion liability indices (Wits-Ehac and Wits-CT Index) have been validated with the actual Wits-Ehac Index and the Wits-CT Index and the results are in-line (Tables 9 and 10). Twenty-eight samples evaluated in this paper with an additional four samples (3 coals- KCA, KCB, KCC and KCD; and one coal-shaleKSA) have confirmed the reliability of the developed 


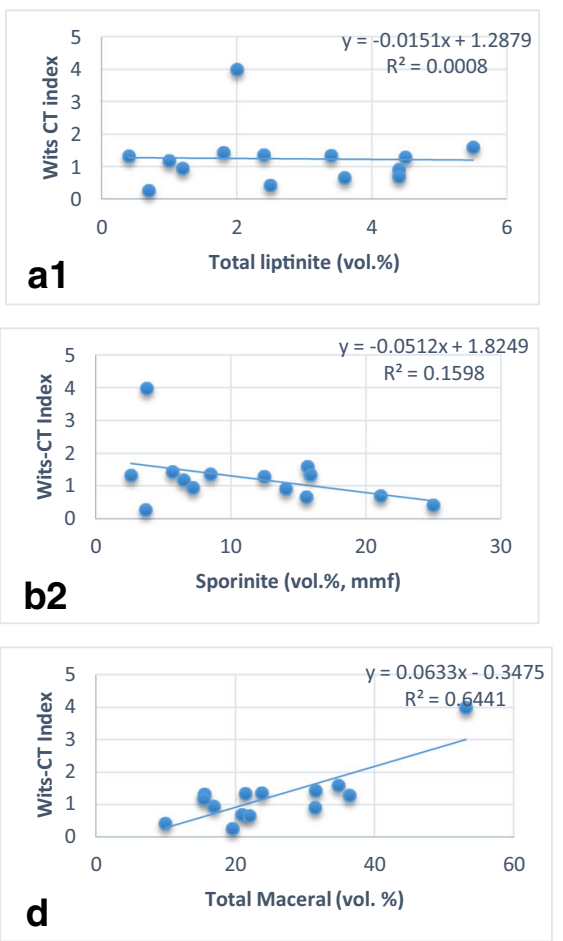

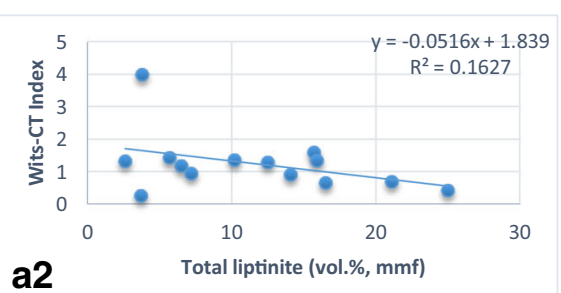
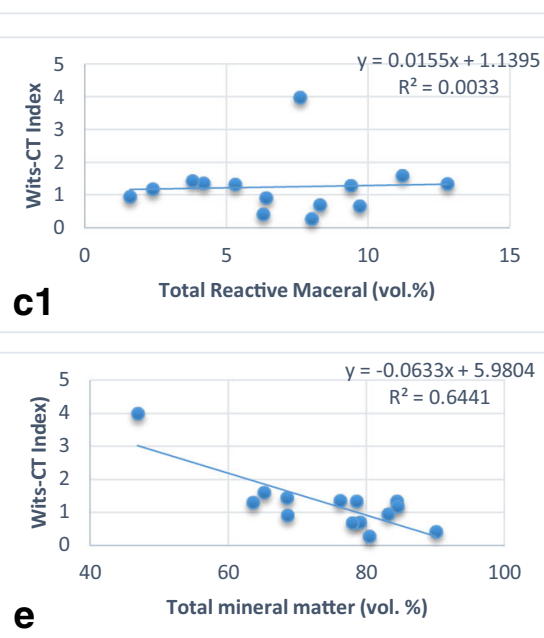
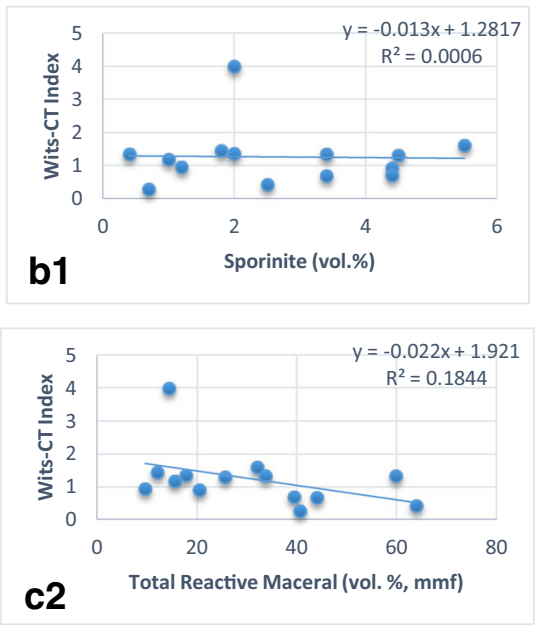

c2

Fig. 16 Influence of liptinite, other macerals, petrographically observable mineral matter and its group on spontaneous combustion of coalshales

Table 2 Relationships between independent (proximate and ultimate analysis, wt $\%$-ad) and dependent variables for coal samples

\begin{tabular}{lccc}
\hline $\begin{array}{l}\text { Independent } \\
\text { variables }\end{array}$ & Range & \multicolumn{2}{l}{$\begin{array}{l}\text { Dependent variables correlation } \\
\text { coefficients }\end{array}$} \\
\cline { 2 - 4 } & & $\begin{array}{l}\text { Wits-Ehac } \\
\text { index }\end{array}$ & $\begin{array}{l}\text { Wits-CT } \\
\text { index }\end{array}$ \\
\hline Moisture & $1.60-2.50$ & $(0.0637)$ & $(0.5847)$ \\
Volatile matter & $16.7-26.9$ & 0.5164 & 0.3273 \\
Ash & $13.7-48.4$ & $(0.6884)$ & $(0.8660)$ \\
Carbon & $36.1-69.7$ & 0.6572 & 0.8565 \\
Hydrogen & $2.55-4.21$ & 0.6616 & 0.7552 \\
Nitrogen & $0.85-1.63$ & 0.6945 & 0.8382 \\
Oxygen & $5.65-10.4$ & $(0.0686)$ & $(0.1016)$ \\
Sulphur & $0.59-5.30$ & $(0.0115)$ & $(0.0687)$ \\
Pyritic sulphur & $0.13-4.13$ & 0.0869 & 0.0553 \\
Sulphate sulphur & $0.01-0.42$ & $(0.6422)$ & $(0.7620)$ \\
Organic sulphur & $0.28-1.09$ & $(0.1787)$ & $(0.2914)$ \\
\hline
\end{tabular}

models. The Wits-Ehac of coal-shales SC, SG, SH, SI, SJ and SM that could not be obtained by the actual Wits-Ehac Index due to their low reactivity were successfully obtained with the predicted models (Table 10). The models present a high level of confidence as they produced results similar to the actual liability indices.

\section{Conclusion}

The statistical analysis showed that the spontaneous combustion liability of coals and coal-shales can be determined by a model consisting of various intrinsic factors. The predicted spontaneous combustion liability indices (WitsEhac and Wits-CT Index) have been validated with the actual Wits-Ehac Index and the Wits-CT Index and the results are in-line. The developed models enable one to identify the most important factors affecting spontaneous combustion and establishes relationships between them. The intrinsic properties of the samples have been identified to be the main factors contributing towards spontaneous combustion in coal mines. However, the study shows that no single factor is sufficient to influence the coal and coalshale spontaneous combustion liability but a cumulative effect of favourable parameters may decide whether a coal or coal-shale will be liable to spontaneous combustion or not. The influence of the intrinsic properties of coal-shales in relation to coals could be a tool to predict spontaneous combustion risk in coal mines. The results provide quantitative descriptions and showed the relationships between the dependence of spontaneous combustion liability indices and intrinsic properties. The linear regression analysis shows that both liability indices indicate better linear relationships with some of the intrinsic factors and thus, 
Table 3 Relationships between independent (petrographic analysis, vol\%) and dependent variables for coal samples

\begin{tabular}{|c|c|c|c|}
\hline \multirow[t]{2}{*}{ Independent variables } & \multirow[t]{2}{*}{ Range } & \multicolumn{2}{|c|}{$\begin{array}{l}\text { Dependent variables } \\
\text { correlation coefficients }\end{array}$} \\
\hline & & $\begin{array}{l}\text { Wits-Ehac } \\
\text { index }\end{array}$ & $\begin{array}{l}\text { Wits-CT } \\
\text { index }\end{array}$ \\
\hline Total vitrinite & $7.0-49.4$ & 0.2591 & 0.0890 \\
\hline Total vitrinite $(\mathrm{mmf})$ & $7.9-60.0$ & 0.0874 & $(0.2755)$ \\
\hline Collotelinite & $1.6-39.0$ & 0.1481 & 0.0255 \\
\hline Collotelinite (mmf) & $1.7-44.4$ & 0.0439 & $(0.2451)$ \\
\hline Collodetrinite & $2.8-13.3$ & 0.3944 & 0.1580 \\
\hline Collodetrinite (mmf) & $3.1-18.8$ & 0.1725 & $(0.2401)$ \\
\hline Total inertinite & $11.7-84.6$ & 0.1679 & 0.4752 \\
\hline Total inertinite (mmf) & $36.9-90.1$ & $(0.0735)$ & 0.2754 \\
\hline Fusinite & $0.8-7.6$ & 0.5663 & 0.2860 \\
\hline Fusinite (mmf) & $1.2-12.1$ & 0.4392 & 0.0447 \\
\hline Secretinite & $0.8-6.0$ & 0.1284 & 0.1143 \\
\hline Secretinite (mmf) & $1.1-6.7$ & 0.0064 & $(0.1791)$ \\
\hline Total semifusinite & $5.5-43.4$ & 0.2898 & 0.3098 \\
\hline $\begin{array}{l}\text { Total semifusinite } \\
\text { (mmf) }\end{array}$ & $14.1-45.9$ & 0.1460 & 0.1010 \\
\hline Total inertodetrinite & $3.2-49.4$ & $(0.0894)$ & 0.4065 \\
\hline $\begin{array}{l}\text { Total inertodetrinite } \\
\text { (mmf) }\end{array}$ & $10-55.5$ & $(0.2768)$ & 0.2504 \\
\hline Total liptinite & $0.6-3.8$ & 0.0280 & 0.2621 \\
\hline Total liptinite (mmf) & $0.6-4.4$ & $(0.2228)$ & $(0.1108)$ \\
\hline Sporinite & $0.4-3.4$ & 0.2321 & 0.4353 \\
\hline Sporinite (mmf) & $0.7-3.8$ & 0.2116 & 0.3235 \\
\hline
\end{tabular}

Table 4 Relationships between independent (total reactive maceral, total maceral and total mineral matter vol.\%) and dependent variables for coal samples

\begin{tabular}{llll}
\hline Independent variables & Range & \multicolumn{2}{l}{$\begin{array}{l}\text { Dependent variables } \\
\text { correlation coefficients }\end{array}$} \\
\cline { 2 - 4 } & & $\begin{array}{l}\text { Wits-Ehac } \\
\text { index }\end{array}$ & $\begin{array}{l}\text { Wits-CT } \\
\text { index }\end{array}$ \\
\hline Total reactive maceral & $11.2-53.0$ & 0.3148 & 0.1292 \\
$\begin{array}{l}\text { Total reactive maceral } \\
\text { (mmf) }\end{array}$ & $12.8-64.4$ & 0.1229 & $(0.2814)$ \\
$\begin{array}{l}\text { Total maceral } \\
\text { Total mineral matter }\end{array}$ & $31.7-94.6$ & 0.3785 & 0.6496 \\
\hline
\end{tabular}

identifies the major intrinsic factors affecting their liability towards spontaneous combustion. It was found each intrinsic property has an influence on spontaneous combustion liability and their strength varies from one another. Also, a definite positive or negative correlation coefficient exists between the intrinsic factors and the spontaneous combustion test results. The multiple regression of spontaneous combustion liability indices on 12 independent
Table 5 Relationships between independent (proximate and ultimate analysis, wt $\%$-ad) and dependent variables for coal-shale samples

\begin{tabular}{llll}
\hline $\begin{array}{l}\text { Independent } \\
\text { variables }\end{array}$ & Range & \multicolumn{2}{l}{$\begin{array}{l}\text { Dependent variables correlation } \\
\text { coefficients }\end{array}$} \\
\cline { 2 - 4 } \cline { 3 - 3 } & & $\begin{array}{l}\text { Wits-Ehac } \\
\text { index }\end{array}$ & $\begin{array}{l}\text { Wits-CT } \\
\text { index }\end{array}$ \\
\hline Moisture & $0.8-1.7$ & 0.7715 & 0.4507 \\
Volatile matter & $8.5-16.6$ & 0.6389 & 0.6901 \\
Ash & $51.5-88.7$ & $(0.8352)$ & $(0.9448)$ \\
Carbon & $2.66-33.7$ & 0.7962 & 0.9630 \\
Hydrogen & $0.75-2.87$ & 0.5795 & 0.8799 \\
Nitrogen & $0.08-0.96$ & 0.6446 & 0.9462 \\
Oxygen & $5.01-11.85$ & $(0.3212)$ & 0.3243 \\
Sulphur & $0.12-6.90$ & 0.5791 & 0.0242 \\
Pyritic sulphur & $0.04-4.26$ & 0.5704 & 0.0367 \\
Sulphate sulphur & $0.01-0.45$ & 0.5365 & $(0.0403)$ \\
Organic sulphur & $0.05-2.19$ & 0.5933 & 0.0147 \\
\hline
\end{tabular}

Table 6 Relationships between independent (petrographic analysisvol\%) and dependent variables for coal-shale samples

\begin{tabular}{|c|c|c|c|}
\hline \multirow[t]{2}{*}{ Independent variables } & \multirow[t]{2}{*}{ Range } & \multicolumn{2}{|c|}{$\begin{array}{l}\text { Dependent variables } \\
\text { correlation coefficients }\end{array}$} \\
\hline & & $\begin{array}{l}\text { Wits-Ehac } \\
\text { index }\end{array}$ & $\begin{array}{l}\text { Wits-CT } \\
\text { index }\end{array}$ \\
\hline Total vitrinite & $0.4-8.4$ & 0.1230 & 0.2620 \\
\hline Total vitrinite (mmf) & $2.4-39.3$ & $(0.2632)$ & $(0.1854)$ \\
\hline Collotelinite & $0-4.2$ & 0.2206 & 0.3366 \\
\hline Collotelinite (mmf) & $0-19.6$ & $(0.1073)$ & $(0.0928)$ \\
\hline Collodetrinite & $0-2.6$ & 0.2105 & 0.1289 \\
\hline Collodetrinite (mmf) & $0-12.1$ & $(0.2330)$ & $(0.1933)$ \\
\hline Total inertinite & $4.9-46.1$ & 0.7360 & 0.8029 \\
\hline Total inertinite (mmf) & $44.9-91.7$ & 0.2143 & 0.3262 \\
\hline Fusinite & $0-4.0$ & $(0.4038)$ & 0.1313 \\
\hline Fusinite (mmf) & $0-16.9$ & $(0.5898)$ & $(0.0427)$ \\
\hline Secretinite & $0-1.8$ & 0.6003 & 0.6009 \\
\hline Secretinite (mmf) & $0-4.8$ & 0.3304 & 0.1523 \\
\hline Total semifusinite & $0.2-8.0$ & 0.7776 & 0.2967 \\
\hline $\begin{array}{l}\text { Total semifusinite } \\
\text { (mmf) }\end{array}$ & $1.3-40.7$ & 0.2970 & $(0.2238)$ \\
\hline Total inertodetrinite & $3.3-35.2$ & 0.7749 & 0.8388 \\
\hline $\begin{array}{l}\text { Total inertodetrinite } \\
\text { (mmf) }\end{array}$ & $25.2-80.5$ & 0.2367 & 0.4460 \\
\hline Total liptinite & $0.4-5.5$ & 0.3360 & $(0.0276)$ \\
\hline Total liptinite (mmf) & $2.6-25.0$ & $(0.0113)$ & $(0.4033)$ \\
\hline Sporinite & $0.4-5.5$ & 0.3463 & $(0.0238)$ \\
\hline Sporinite (mmf) & $2.6-25.0$ & 0.0059 & $(0.3997)$ \\
\hline
\end{tabular}

variables has developed acceptable and accurate predictive models as indicated by R-squared values, the coefficient of correlations and standard error of estimates. The models 
Table 7 Relationships between independent (total reactive maceral, total maceral and total mineral matter vol\%) and dependent variables for coal-shale samples

\begin{tabular}{llll}
\hline Independent variables & Range & \multicolumn{2}{l}{$\begin{array}{l}\text { Dependent variables } \\
\text { correlation coefficients }\end{array}$} \\
\cline { 3 - 4 } & & $\begin{array}{l}\text { Wits-Ehac } \\
\text { index }\end{array}$ & $\begin{array}{l}\text { Wits-CT } \\
\text { index }\end{array}$ \\
\hline Total reactive maceral & $1.6-12.8$ & 0.2923 & 0.0575 \\
$\begin{array}{l}\text { Total reactive maceral } \\
(\text { mmf })\end{array}$ & $9.6-63.9$ & $(0.2552)$ & $(0.4294)$ \\
$\begin{array}{l}\text { Total maceral } \\
\text { Total mineral matter }\end{array}$ & $9.9-53.1$ & 0.7653 & 0.8026 \\
\hline
\end{tabular}

derived from the different samples produced high correlation coefficients and low standard error of estimates. The use of the formulas derived may provide reliable predictions for the spontaneous combustion liability of coals and coal-shales. The influence of the intrinsic properties affecting the spontaneous combustion of coals and coalshales may be evaluated more effectively by these models than by the linear regression. The results obtained from this study may be used as a reliable tool to support previous works on the role of intrinsic properties on the spontaneous
Table 9 Actual and predicted Wits-Ehac and Wits-CT index for coals

\begin{tabular}{lllllc}
\hline \multirow{2}{*}{ Samples } & \multicolumn{2}{l}{ Wits-Ehac index } & & \multicolumn{2}{l}{ Wits-CT index } \\
\cline { 2 - 3 } \cline { 5 - 6 } & Actual & Predicted & & Actual & Predicted \\
\hline CA & 4.64 & 4.82 & & 6.29 & 5.88 \\
CB & 4.64 & 4.67 & & 6.96 & 6.90 \\
CC & 4.52 & 4.52 & & 5.31 & 5.32 \\
CD & 4.60 & 4.64 & & 6.80 & 6.71 \\
CE & 4.76 & 4.63 & & 5.42 & 5.73 \\
CF & 4.49 & 4.49 & & 3.97 & 3.98 \\
CG & 4.91 & 4.82 & & 7.53 & 7.74 \\
CH & 4.69 & 4.70 & & 7.51 & 7.49 \\
CI & 3.82 & 3.83 & & 4.05 & 4.03 \\
CJ & 4.46 & 4.45 & & 6.61 & 6.63 \\
CK & 4.44 & 4.62 & & 9.10 & 8.98 \\
CL & 4.87 & 4.85 & & 9.59 & 9.64 \\
CM & 4.76 & 4.63 & & 7.27 & 7.47 \\
CN & 4.84 & 4.79 & & 7.91 & 8.03 \\
KCA & 6.07 & 6.03 & 8.87 & 8.57 \\
KCB & 5.41 & 5.25 & 8.55 & 8.78 \\
KCC & 5.67 & 5.67 & 10.51 & 10.83 \\
KCD & 6.44 & 6.41 & 9.01 & 9.26 \\
\hline & & & &
\end{tabular}

Table 8 Predictive formulas derived by multiple regression analysis

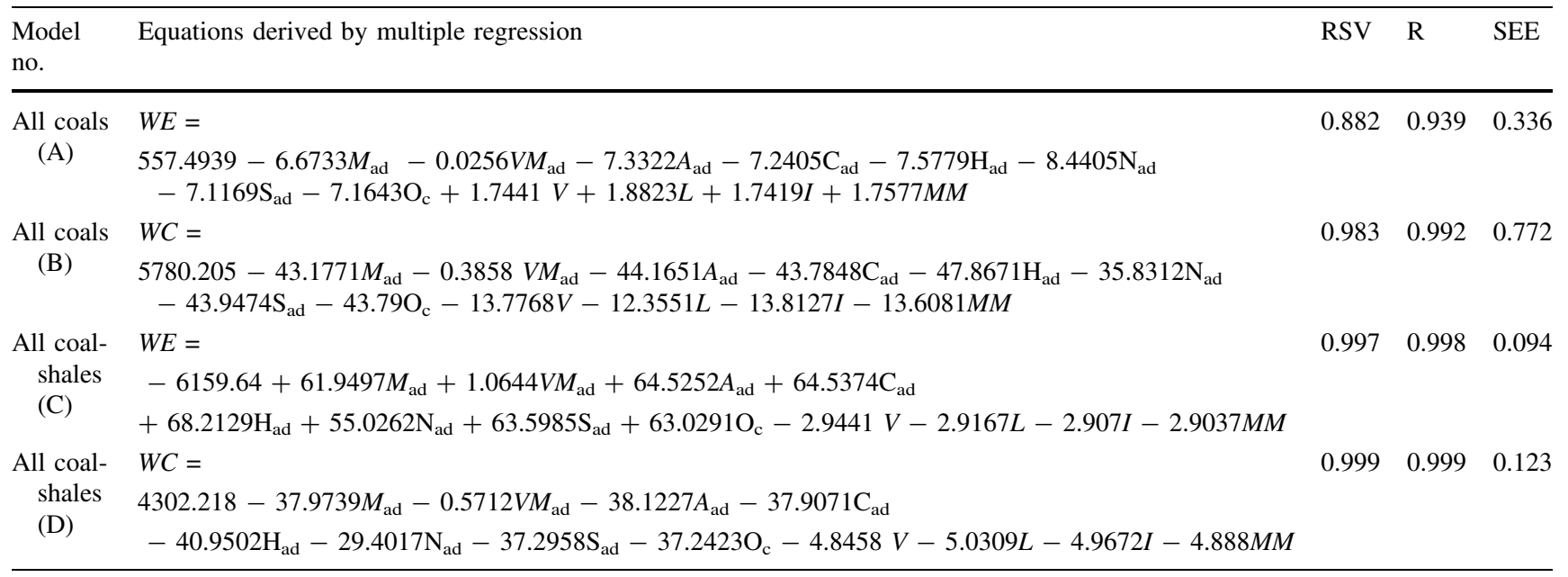

$M_{\mathrm{ad}}$ is air-dried moisture (wt $\left.\%\right), V M_{\mathrm{ad}}$ is air-dried volatile matter (wt $\left.\%\right), A_{\mathrm{ad}}$ is air-dried ash (wt $\left.\%\right), \mathrm{C}_{\mathrm{ad}}$ is air-dried carbon (wt $\left.\%\right), \mathrm{H}_{\mathrm{ad}}$ is air-dried hydrogen (wt $\%), \mathrm{N}_{\mathrm{ad}}$ is air-dried nitrogen (wt $\left.\%\right), \mathrm{S}_{\mathrm{ad}}$ is air-dried sulphur (wt $\left.\%\right), \mathrm{O}_{\mathrm{c}}$ is calculated oxygen (wt $\%$ ), $V$ is total vitrinite (vol\%), $L$ is total liptinite (vol\%), $I$ is total inertinite (vol\%), $M M$ is mineral matter (vol\%), WE is Wits-Ehac Index, $W C$ is Wits-CT index, $R S V$ is R-squared values, $\mathrm{R}$ is correlation coefficient, and SEE is standard error of estimate 
Table 10 Actual and predicted Wits-Ehac and Wits-CT index for coal-shales

\begin{tabular}{llllll}
\hline Samples & \multicolumn{2}{l}{ Wits-Ehac index } & & \multicolumn{2}{l}{ Wits-CT index } \\
\cline { 2 - 3 } \cline { 6 - 6 } & Actual & Predicted & & Actual & Predicted \\
\hline SA & 3.09 & 3.07 & & 1.33 & 1.37 \\
SB & 3.08 & 3.08 & & 1.30 & 1.28 \\
SC & - & 2.56 & & 0.91 & 0.97 \\
SD & 3.27 & 3.31 & & 0.70 & 0.67 \\
SE & 3.73 & 3.72 & & 1.60 & 1.61 \\
SF & 3.10 & 3.07 & & 1.36 & 1.40 \\
SG & - & 2.49 & & 0.67 & 0.63 \\
SH & - & 2.35 & & 0.27 & 0.28 \\
SI & - & 2.58 & & 0.95 & 0.88 \\
SJ & - & 2.63 & & 0.42 & 0.42 \\
SK & 2.98 & 2.98 & & 1.18 & 1.18 \\
SL & 2.99 & 2.99 & & 1.34 & 1.35 \\
SM & - & 2.54 & & 1.44 & 1.43 \\
SN & 3.77 & 3.79 & 3.99 & 3.97 \\
KSA & 3.49 & 3.50 & 4.40 & 4.38 \\
\hline
\end{tabular}

combustion of coals and coal-shales. It has been found that an accurate characterisation of the degree of oxidation could be a useful tool to measure the relative liability of carbonaceous materials toward spontaneous combustion.

Acknowledgements This work was conducted in the context of coalshale spontaneous combustion in the Witbank coalfields, South Africa and was financially sponsored by Coaltech. The authors wish to express gratitude to Coaltech and the staff of the selected coal mines for their supports. The work presented here is part of a Ph.D. research study in the School of Mining Engineering at the University of the Witwatersrand.

Open Access This article is distributed under the terms of the Creative Commons Attribution 4.0 International License (http://crea tivecommons.org/licenses/by/4.0/), which permits unrestricted use, distribution, and reproduction in any medium, provided you give appropriate credit to the original author(s) and the source, provide a link to the Creative Commons license, and indicate if changes were made.

\section{References}

ASTM (D-3173-17a) (2017) Standard test methods for moisture in the analysis sample of coal and coke. ASTM International, West Conshohocken, PA. www.astm.org

ASTM (D-3174-11) (2011) Standard test method for ash in the analysis sample of coal and coke from coal and standard classification of coals by rank. ASTM International, West Conshohocken, PA. www.astm.org

ASTM (D-3175-17) (2017) Standard test method for volatile matter in the analysis sample of coal and coke. ASTM International, West Conshohocken, PA. www.astm.org

ASTM (D3176-15) (2015) Standard practice for ultimate analysis of coal and coke and standard test methods for total sulfur in the analysis sample of coal and coke. ASTM International, West Conshohocken, PA, www.astm.org

Banerjee SC (1985) Spontaneous combustion of coal and mine fires. Oxford and IBH Publishing, New Delhi

Beamish BB, Arisoy A (2008) Effect of mineral matter on coal selfheating rate. Fuel $87: 125-130$

Beamish BB, Blazak DG (2005) Relationship between ash content and R70 self-heating rate of callide coal. Int J Coal Geol 64:126-132

Beamish BB, Barakat MA, St George JD (2001) Spontaneous combustion propensity of NewZealand coals under adiabatic conditions. Int J Coal Geol 45:217-224

Carras J, Young B (1994) Self-heating of coal and related materials: models, application and test methods. Prog Energy Combust Sci 20(1):1-15

Cliff D, Davis R, Bennet A, Galvin G, Clarkson F (1998) Large scale laboratory testing of the spontaneous combustibility of Australia coals. In: Proceedings of Queensland mining industry health \& safety conference, Yeppoon, pp 175-179

Deborah JR (2016) Statistics for dummies, 2nd edition, pp 408

Draper NR, Smith H (1998) Applied regression analysis. Wileyinterscience. ISBN 0-471-17082-8

Dullien F (1979) Porous media fluid transport and pore structure. Academic Press, London, p 79

Eroglu HN (1992) Factors affecting spontaneous combustion liability index. Ph.D Thesis, University of the Witwatersrand Johannesburg, South Africa

Falcon LM (1987) The petrographic composition of Southern African Coals in relation to friability, hardness and abrasive indices. Inst Min Metall 87:323-336

Falcon RMS (2004) The constitution of coal and its inherent capacity to self-heat as applied to an integrated spontaneous combustion risk. In: Final proceedings of the international conference in spontaneous combustion. Fossil fuel foundation and SABS, Johannesburg, 8-9

Genc B, Cook A (2015) Spontaneous combustion risk in South African coalfields. J S Afr Inst Min Metall 115:563-568

Genc B, Onifade M, Cook A (2018) Spontaneous combustion risk on South African coalfields: Part 2. In: Proceedings of the 21st International Coal Congress of Turkey 'ICCET' April 11-13, 2018, Zonguldak, Turkey, pp 13-25

Glant SA, Slinker BK (1990) Primer of applied regression and analysis of variance, ISBN 0-07-023407-8. McGraw-Hill, New York

Gouws MJ, Wade L (1989a) The self-heating liability of coal: predictions based on simple indices. Min Sci Technol 9:75-80

Gouws MJ, Wade L (1989b) The self-heating liability of coal: predictions based on composite indices. Min Sci Technol 9:81-85

Humphreys D, Rowlands D, Cudmore JF (1981) Spontaneous combustion of some Queensland coals. In: Proceedings of the fifth ignitions, explosions and fires in coal mines symposium. Australasian Institute of Mining and Metallurgy, Melbourne, pp 1-19

ISO 12902 (200)1 Determination of total carbon, hydrogen and nitrogen

Kaymakci E, Didari V (2002) Relations between coal properties and spontaneous combustion parameters. Turk J Eng Environ Sci 26(1):59-64

Kim AG (1977) Laboratory studies on spontaneous combustion of coal. IC 8756. US Bureau of Mines

Kucuk A, Kadioglu Y, Gulaboglu MS (2003) A study of spontaneous combustion characteristics of a Turkish lignite: particle size, moisture of coal, humditiy of air. Combust Flame 133(3):255-261 
Moghtaderi B, Dlugogorski BZ, Kennedy EM (2000) Effects of wind flow on self-heating characteristics of coal stockpiles. Trans IChemE 78(6):445-453

Nimaje DS, Tripathy DP (2016) Characterization of some Indian coals to assess their liability to spontaneous combustion. Fuel 163:139-147

Onifade M, Genc B (2018a) Establishing relationship between spontaneous combustion liability indices. In: Proceedings of the 21st international coal congress of Turkey "ICCET" April 11-13, Zonguldak, Turkey, pp 1-11

Onifade M, Genc B (2018b) Prediction of the spontaneous combustion liability of coal and coal-shale using statistical analysis. In: 6th regional conference of Society of mining professors, pp 63-82

Onifade M, Genc B (2018c) A review of spontaneous combustion studies-South African context. Int J Min Reclamation Environ. https://doi.org/10.1080/17480930.2018.1466402

Onifade M, Genc B (2018d) Spontaneous combustion of coals and coal-shales. Int J Min Sci Technol. https://doi.org/10.1016/j. ijmst.2018.05.013

Onifade M, Genc B, Carpede A (2018) A new apparatus to establish the spontaneous combustion propensity of coals and coal-shales. Int J Min Sci Technol. https://doi.org/10.1016/j.ijmst.2018.05. 012

Panigrahi DC, Sahu HB (2004) Classification of coal seams with respect to their spontaneous combustion susceptibility-a neural network approach. Geotech Geol Eng 22:457-476

Panigrahi DC, Saxena VK (2001) An investigation into spontaneous combustion characteristics of coals using differential thermal analysis. In: Proceedings of the 7th international mine ventilation congress, EMAG, Krakow, 17-22 June 2001, pp 495-500

Ren TX, Edwards JS, Clarke D (1999) Adiabatic oxidation study on the propensity of pulverized coal to spontaneous combustion. Fuel 78:1611-1620
Sahu HB, Panigrahi DC, Mishra NM (2005) Assessment of spontaneous combustion susceptibility of coal seams by experimental techniques: a comparative study. In: International symposium on advances in mining technology and management, pp 459-465

SANS, 7404 Parts 1-5 Methods for the petrography analysis of coals. Part 2: Methods of preparing coal samples

Scott AC, Glasspool IJ (2007) Observations and experiments on the origin and formation of inertinite group macerals. Int J Coal Geol 70(1-3):53-66

Singh RN, Demirbilek S (1987) Statistical appraisal of intrinsic factors affecting spontaneous combustion of coal. Min Sci Technol 4(2):155-165

Smith AC, Miron Y, Lazzara P (1988) Inhibition of spontaneous combustion of coal. Report of Investigation RI 9196. Bureau of Mines, US

Stigler SM (1989) Francis Galton's account of the invention of correlation. Stat Sci 4(2):73-79

Stott JB (1980) The spontaneous combustion of coal and the role of moisture transfer, US: Final Report. Bureau of Mines, US

Stracher GB, Taylor TP (2004) Coal fires burning out of control around the world: thermodynamic recipe for environmental catastrophie. Int J Coal Geol 59(1):7-17

Uludag S, Phillips HR, Eroglu HN (2001) Assessing spontaneous combustion risk in South African coal mining by using a GIS tool. In: 17th international mining conference and exhibition, Turkey, pp 243-249

Wade L (1989) The propensity of South African coals to spontaneously combust. Ph.D. Thesis, Department of Mining Engineering, University of the Witwatersrand, Johannesburg

Wade L, Gouws MJ, Phillips HR (1987) An apparatus to establish the spontaneous combustion propensity of South African coals. In: Proceedings of the symposium on safety in coal mines, CSIR, Pretoria. pp 7.1-7.2 